\title{
Sparks and Puffs in Oligodendrocyte Progenitors: Cross Talk between Ryanodine Receptors and Inositol Trisphosphate Receptors
}

\author{
Laurel L. Haak, ${ }^{1}$ Long-Sheng Song, ${ }^{2}$ Tadeusz F. Molinski, ${ }^{3}$ Isaac N. Pessah, ${ }^{4}$ Heping Cheng, ${ }^{2,5}$ and \\ James T. Russell ${ }^{1}$ \\ ${ }^{1}$ National Institute of Child Health and Human Development, National Institutes of Health $(\mathrm{NIH})$, Bethesda, Maryland \\ 20892, ${ }^{2}$ National Institute on Aging, NIH, Baltimore, Maryland 21224, Departments of ${ }^{3}$ Chemistry and ${ }^{4}$ Molecular \\ Bioscience, School of Veterinary Medicine, University of California, Davis, California 95616, and 5 National Laboratory of \\ Biomembranes and Membrane Biotechnology, College of Life Sciences, Peking University, Beijing 100871, China
}

Investigating how calcium release from the endoplasmic reticulum (ER) is triggered and coordinated is crucial to our understanding of how oligodendrocyte progenitor cells (OPs) develop into myelinating cells. Sparks and puffs represent highly localized $\mathrm{Ca}^{2+}$ release from the ER through ryanodine receptors (RyRs) and inositol trisphosphate receptors ( $\left(\mathrm{P}_{3} \mathrm{Rs}\right)$, respectively. To study whether sparks or puffs trigger $\mathrm{Ca}^{2+}$ waves in OPs, we performed rapid high-resolution line scan recordings in fluo-4-loaded OP processes. We found spontaneous and evoked sparks and puffs, and we have identified functional cross talk between $\mathrm{IP}_{3} \mathrm{Rs}$ and RyRs. Local events evoked using the $\mathrm{IP}_{3}$-linked agonist methacholine (MeCh) showed significantly different morphology compared with events evoked using the caffeine analog 3,7-dimethyl-1-propargylxanthine (DMPX). Pretreatment with MeCh potentiated DMPX-evoked events, whereas inhibition of RyRs potentiated events evoked

Oligodendrocyte progenitors (OPs) must migrate and proliferate before differentiating into myelinating cells. During oligodendrocyte development, nearby neurons and astrocytes release growth factors and neurotransmitters that increase intracellular calcium $\left(\left[\mathrm{Ca}^{2+}\right]_{\mathrm{i}}\right)$ in OPs. $\mathrm{Ca}^{2+}$ mediates several developmental processes. Kirischuk et al. (1995) have proposed that subcellular $\mathrm{Ca}^{2+}$ increases in OP processes initiate myelin formation. Platelet-derived growth factor (PDGF) promotes proliferation and migration in vitro (Noble et al., 1988; Barres and Raff, 1993; Barres et al., 1993) and in vivo (Calver et al., 1998; Redwine and Armstrong, 1998) through a $\mathrm{Ca}^{2+}$-dependent pathway (Simpson and Armstrong, 1999). PDGF evokes $\mathrm{Ca}^{2+}$ oscillations in cultured OPs (Fatatis and Miller, 1997).

\footnotetext{
Received Oct. 18, 2000; revised Feb. 15, 2001; accepted Feb. 23, 2001.

This work was supported by a National Research Council Research Associateship to L.L.H. and National Institutes of Health Grants 1RO3 10173 and 1PO 05707 to I.N.P. H.C. is an Outstanding Young Investigator of the National Natural Sciences Foundation of China. We thank Lynne A. Holtzclaw and Dongmei Yang for technical assistance and Dr. Maurizio Grimaldi for critical reading of this manuscript. The technical assistance of Huong Huynh in performing the measurements of SERCA activity is gratefully acknowledged.

Correspondence should be addressed to James T. Russell, Laboratory of Cellular and Molecular Neurophysiology, National Institutes of Health, Building 49, Room 5A78, 49 Convent Drive, Bethesda, MD 20814. E-mail: james@helix.nih.gov.

Reprint requests should be addressed to Heping Cheng, National Institute on Aging, National Institutes of Health, Gerontology Research Center, Room 3D-09, 5600 Nathan Shock Drive, Baltimore, MD 21224. E-mail: chengp@grc.nia.nih.gov. Copyright (C) 2001 Society for Neuroscience $0270-6474 / 01 / 213860-11 \$ 15.00 / 0$
}

by low concentrations of MeCh. Furthermore, activation of $\mathrm{IP}_{3} \mathrm{Rs}$ but not RyRs was critical for $\mathrm{Ca}^{2+}$ wave initiation. Using immunocytochemistry, we show OPs express the specific $\mathrm{Ca}^{2+}$ release channel subtypes $\mathrm{RyR} 3$ and $\mathrm{IP}_{3} \mathrm{R} 2$ in patches along OP processes. RyRs are coexpressed with $\mathrm{IP}_{3} \mathrm{Rs}$ in some patches, but $I P_{3} R s$ are also found alone. This differential distribution pattern may underlie the differences in local and global $\mathrm{Ca}^{2+}$ signals mediated by these two receptors. Thus, in OPs, interactions between $\mathrm{IP}_{3} \mathrm{Rs}$ and RyRs determine the spatial and temporal characteristics of calcium signaling, from microdomains to intracellular waves.

Key words: calcium; confocal microscopy; cross talk; development; IP 3 receptor; muscarinic receptor; ryanodine receptor; oligodendrocyte progenitor; puffs; SERCA; sparks; Xestospongin C; wave
Activation of muscarinic $\mathrm{m} 1$ receptors in OPs increases inositol 1,4,5-trisphosphate $\left(\mathrm{IP}_{3}\right)$ and $\left[\mathrm{Ca}^{2+}\right]_{\mathrm{i}}$ (Cohen and Almazan, 1994) and is linked to $\mathrm{Ca}^{2+}$-dependent gene transcription (Pende et al., 1997; Sato-Bigbee et al., 1999). Muscarinic receptorstimulated $\left[\mathrm{Ca}^{2+}\right]_{\mathrm{i}}$ increases may also play a role in OP proliferation (Cohen et al., 1996) but do not induce migration (Simpson and Armstrong, 1999). We have been studying muscarinic agonist-mediated $\mathrm{Ca}^{2+}$ signals in OPs, and we have found that $\mathrm{Ca}^{2+}$ stores and release machinery are colocalized along OP processes (Simpson et al., 1997), in effect forming specialized "rafts" (Krämer et al., 1999). We were interested in studying microdomains of $\mathrm{Ca}^{2+}$ release in more detail because localization of $\mathrm{Ca}^{2+}$ signals is one way to regulate specific cellular processes.

Many cell types show highly localized $\mathrm{Ca}^{2+}$ release events. " $\mathrm{Ca}^{2+}$ puffs" represent local $\mathrm{Ca}^{2+}$ release from the endoplasmic reticulum (ER) through $\mathrm{IP}_{3}$-gated ion channels $\left(\mathrm{IP}_{3} \mathrm{Rs}\right.$ ) (for review, see Parker et al., 1996). Puffs arise from discrete sites at low $\mathrm{IP}_{3}$ levels and become coordinated at higher $\mathrm{IP}_{3}$ levels to produce global $\mathrm{Ca}^{2+}$ waves and oscillations (Marchant and Parker, 1998). Local $\mathrm{Ca}^{2+}$ release can also be mediated by $\mathrm{Ca}^{2+}$-activated ryanodine receptors (RyRs). These events, called " $\mathrm{Ca}^{2+}$ sparks", have kinetic and spatial profiles smaller than puffs (for review, see Cheng et al., 1996). The hierarchical organization of $\mathrm{Ca}^{2+}$ release from intracellular stores ranging from sparks and puffs to larger subcellular events and ultimately to global $\mathrm{Ca}^{2+}$ 
waves suggests that cells can use considerable flexibility in the temporal and spatial pattern of a $\mathrm{Ca}^{2+}$ response (Thomas et al., 1998). Cross talk between signaling pathways may add another level of complexity (Sun et al., 1997).

In this study, we investigated local $\mathrm{Ca}^{2+}$ release events underlying wave initiation in OPs. We show that OPs express specific subtypes of $\mathrm{IP}_{3} \mathrm{Rs}$ and RyRs, which has implications for $\mathrm{Ca}^{2+}$ release inactivation and wave initiation. We applied high-speed line scan confocal imaging analysis to study the role of these intracellular $\mathrm{Ca}^{2+}$ channels in local and global $\mathrm{Ca}^{2+}$ signaling. Activation of either $\mathrm{IP}_{3} \mathrm{Rs}$ or RyRs produced kinetically distinct local $\mathrm{Ca}^{2+}$ release events, however cross talk between these receptors significantly altered these kinetics. Thus, RyRs and $\mathrm{IP}_{3} \mathrm{Rs}$ can interact to shape $\mathrm{Ca}^{2+}$ signals in OPs. Interestingly, only $\mathrm{IP}_{3} \mathrm{R}$ activation was able to evoke $\mathrm{Ca}^{2+}$ waves in OPs. Investigating how local $\mathrm{Ca}^{2+}$ release events are triggered and coordinated is crucial to our understanding of how OPs develop into myelinating cells.

\section{MATERIALS AND METHODS}

OP culture preparation. OPs were obtained from 2-d-old rat pups, as previously described (Simpson and Russell, 1996). Cortices were removed, stripped of meninges, then minced and briefly digested with trypsin at $37^{\circ} \mathrm{C}$. Tissue was manually dissociated and plated on plastic 75 $\mathrm{cm}^{2}$ flasks. Cells were maintained at $5 \% \mathrm{CO}_{2}$ and $37^{\circ} \mathrm{C}$ in DMEM with $10 \%$ FBS, $1 \%$ Pen/Strep, and fungizone. After 7-9 d, the flasks were shaken at $37^{\circ} \mathrm{C}$ for $3 \mathrm{hr}$, medium was changed, then flasks were shaken overnight. Supernatant was spun down, resuspended, and plated onto a plastic Petri dish for 45 min to allow any endothelial cells, macrophages, and microglia to attach. OPs were highly enriched $(>90 \%)$ in the resulting supernatant. Cells were plated onto poly-D-ornithine-coated $20 \mathrm{~mm}$ glass coverslips at a density of $1 \times 10^{-5}$ cells per slip. After $1 \mathrm{hr}$, medium was replaced with serum-free N1 medium and supplemented daily with 1 $\mu \mathrm{g} / \mathrm{ml}$ PDGF. Enriched OP cultures were maintained at $10 \% \mathrm{CO}_{2}, 37^{\circ} \mathrm{C}$. OPs were studied within $2 \mathrm{~d}$ of plating.

Immunocytochemistry. Cells were rinsed in PBS, $\mathrm{pH} 7.2$, fixed in cold $4 \%$ paraformaldehyde for 4 min, rinsed in PBS, and permeabilized in ice-cold $100 \%$ methanol. After rinsing, cells were incubated overnight at $4^{\circ} \mathrm{C}$ with primary antibody diluted in $10 \%$ goat serum. We used the specific anti-rabbit polyclonal $\mathrm{IP}_{3} \mathrm{R}$ antibodies for type 1 (1:100; Sharp et al., 1999), type 2, or type 3 receptors (1:100; Affinity Bioreagents, Boulder, CO). We also used a monoclonal RyR antibody (1:100; Calbiochem, La Jolla, CA), a type $1 / 2$ anti-RyR antibody (34C; University of Iowa Hybridoma Bank; Walton et al., 1991) or an anti-rabbit polyclonal RyR type 3 antibody (1:100). The RyR3 antibody was raised against a specific C-terminal sequence of the RyR3 and has been shown to selectively recognize the mammalian RyR3 and avian $\beta$-RyR (Murayama and Ogawa, 1996). Cells were rinsed, then incubated for $1 \mathrm{hr}$ with the appropriate FITC- or Rhodamine Red-X (RRX) conjugated secondary antibody (1:200; Jackson ImmunoResearch, West Grove, PA). For dual RyR3-IP ${ }_{3} \mathrm{R} 2$ staining, we used an anti-RyR3 antibody (1:100) raised in a goat and an anti-I $P_{3} R 2$ antibody (1:100) raised in a rabbit (Affinity Bioreagents) diluted in 10\% donkey serum, and FITC donkey anti-goat and RRX donkey anti-rabbit secondary antibodies (1:200; Jackson ImmunoResearch). After rinsing, coverslips were mounted using Mowiol (Calbiochem). Background fluorescence was assessed in cells incubated with secondary antibody only. Immunofluorescence was visualized using a $40 \times$ Zeiss Pan-Neofluar 1.30 NA objective and a Zeiss 510 confocal microscope. The pinhole was set for a $<0.9 \mu \mathrm{m}$ optical section. FITC was excited using the argon ion laser $488 \mathrm{~nm}$ line; RRX staining was excited using the HeNe laser $543 \mathrm{~nm}$ line.

Microscopy of $\mathrm{Ca}^{2+}$ events. Coverslips were loaded into a Leiden perfusion chamber, then OPs were loaded for $18 \mathrm{~min}$ at room temperature with $10 \mu \mathrm{g} / \mathrm{ml}$ fluo-3 AM or fluo-4 AM (Molecular Probes, Eugene, $\mathrm{OR})$. Indicator dyes $(1000 \times)$ were suspended in $\mathrm{DMSO} / 10 \%$ pluronic acid. Bipolar OPs were selected for study that had long, straight processes with no crossing processes in the field of view. Cells were continuously perfused. Drugs and perfusion medium were applied locally through a multibarrel pipette; solutions were changed using stopcocks. The composition of standard perfusion medium was (in $\mathrm{mm}$ ): $130 \mathrm{NaCl}, 5.36 \mathrm{KCl}$,
$0.8 \mathrm{MgSO}_{4}, 1 \mathrm{Na}_{2} \mathrm{HPO}_{4}, 25$ glucose, 20 HEPES, 1 Na-pyruvate, 1.50 $\mathrm{CaCl}_{2}$, and 1 ascorbic acid, $\mathrm{pH} 7.3, \sim 320$ mOsm.

Line scans were performed using a Zeiss LSM-410 inverted microscope fitted with a Zeiss Plan-Neofluor $40 \times$ oil-immersion 1.3 NA objective, with excitation at the $488 \mathrm{~nm}$ line of an argon ion laser (Song et al., 1997). The optical resolution of the microscope was $0.5 \mu \mathrm{m}$ in the horizontal plane and $1.0 \mu \mathrm{m}$ in depth, determined using $0.09 \mu \mathrm{m}$ fluorescent beads (Molecular Probes). Events were recorded in the line scan imaging mode at $4.3776 \mathrm{msec}$ per 512 pixel line. One or more 512 pixel $\times$ 1024 line images (4.483 sec/image) were obtained per experiment.

Global $\left[\mathrm{Ca}^{2+}\right]_{\mathrm{i}}$ changes were studied using an inverted wide angle microscope. Cells were imaged using a Nikon $40 \times 1.3 \mathrm{NA} \mathrm{CF}$ Fluor DL oil immersion lens or a Nikon $20 \times$ Fluor 0.75 NA lens. Fluorescence images were acquired at 495 excitation and 510 emission through a microchannel plate intensifier with a CCD camera. Images were captured every 1 or $2 \mathrm{sec}$, then digitized (Yagodin et al., 1994). Nonzero pixels within each region of interest were averaged and plotted as $\Delta F / F_{\mathrm{o}}$ versus time.

Histogram data were plotted using KaleidaGraph (Synergy Software, Reading, PA). Data are reported as mean \pm SEM. Data were tested for significance using Welch's $t$ test. Statistics were performed using InStat (GraphPad, San Diego, CA).

Detection and classification of local $\mathrm{Ca}^{2+}$ events. Line scan data were analyzed and plotted using the IDL software environment (Research Systems Inc., Boulder, $\mathrm{CO}$ ). Local $\mathrm{Ca}^{2+}$ release events were identified and measured in OPs using an algorithm developed by Cheng et al. (1999) in a slightly modified form. This algorithm selected events based on statistical deviation from background noise. A manual version of this algorithm allows some user input to locate event onsets in $3 \times 3$ median and space-time $(0.8 \mu \mathrm{m}, 17 \mathrm{msec}$, or $6 \times 4$ window $)$ smoothed images. Once a putative event onset is identified the algorithm: (1) measures the mean and SD of the local baseline image intensity $\left(F_{\mathrm{o}}\right)$, (2) locates the event peak by searching locally for points $>3$ SD above the background intensity, and (3) locates the event $x-y$ coordinates. Several parameters are measured, including peak $(F)$ and normalized intensity $\left(F / F_{\mathrm{o}}\right)$, full width at half maximum (FWHM, in micrometers), full duration at half maximum (FDHM, in milliseconds), rise time ( $T_{\text {peak }}$, in milliseconds), and decay time ( $T_{\text {decay }}$, in milliseconds). The manual version was used because of the wide variation of event sizes in OPs and to discard false detections caused by dim signal or excess noise.

Preparation of membranes enriched in sarcoendoplasmic reticulum calcium ATPase-1. Sarcoplasmic reticulum (SR) membrane vesicles enriched in sarcoendoplasmic reticulum calcium ATPase-1 (SERCA-1) were prepared from back and hindlimb skeletal muscles of New Zealand White rabbits according to the method of Saito et al. (1984). SERCA2-enriched vesicles were prepared from rat cardiac ventricle. The preparations were stored in $10 \%$ sucrose, $5 \mathrm{~mm}$ imidazole, $\mathrm{pH} 7.4$, at $-80^{\circ} \mathrm{C}$ until needed.

$\mathrm{Ca}^{2+}\left(\mathrm{Mg}^{2+}\right)$ ATPase activity. Rates of SERCA-mediated ATP hydrolysis were determined directly using a coupled enzyme assay that measures the oxidation of NADH as a linear decrease in absorbance at $340 \mathrm{~nm}$ (Schwartz et al., 1969). SR membrane vesicles (50 $\mu \mathrm{g}$ of protein) were added to the temperature-controlled cuvettes at $37^{\circ} \mathrm{C}$ containing assay buffer consisting of $5 \mathrm{~mm} \mathrm{HEPES,} \mathrm{pH} \mathrm{7.0,} 100 \mathrm{~mm} \mathrm{KCl,} 5 \mathrm{mM} \mathrm{MgCl}_{2}, 60$ $\mu \mathrm{M}$ EGTA, $100 \mu \mathrm{M} \mathrm{CaCl} 2,0.3 \mathrm{~mm}$ sucrose, $2 \mathrm{~mm}$ phospho(enol)pyruvate, $0.8 \mathrm{~mm} \mathrm{NADH}, 24 \mathrm{U} / \mathrm{ml} \mathrm{LDH}, 16.8 \mathrm{U}$ of pyruvate kinase, and $1.5 \mu \mathrm{g} / \mathrm{ml}$ of the $\mathrm{Ca}^{2+}$ ionophore A23187 (final volume $1.2 \mathrm{ml}$ ). Xestospongin $\mathrm{C}$ (XeC) $(10-100 \mu \mathrm{M})$ or equivalent methanol or DMSO vehicle controls were introduced into test cuvettes $15-60 \mathrm{~min}$ before the start of the reaction. After zeroing the spectrophotometer, reactions were started by addition of $1 \mathrm{mM} \mathrm{Na}_{2} \mathrm{ATP}$, and the total ATPase activity (measured as a linear decline in NADH absorbance) was monitored for at least $30 \mathrm{sec}$. The $\mathrm{Ca}^{2+}$-independent (non-SERCA) component of ATPase activity was measured by the addition of either $4 \mathrm{~mm} \mathrm{~K}_{2}$ EGTA or $100 \mathrm{~nm}$ thapsigargin to the reaction mixture. $\mathrm{Ca}^{2+}$-dependent rates were calculated as the difference between total ATPase and $\mathrm{Ca}^{2+}$-independent rates. Each experimental condition was repeated 3-5 times, and the data represent mean $\pm \mathrm{SD}$.

Macroscopic $\mathrm{Ca}^{2+}$ transport measurement. $\mathrm{Ca}^{2+}$ transport across SR vesicles was measured with the membrane-impermeant $\mathrm{Ca}^{2+}$-sensitive dye, antipyrylazo III (APIII), using a diode array spectrophotometer (model 8452; Hewlett Packard, Palo Alto, CA). Skeletal SR vesicles (50 $\mu \mathrm{g} / \mathrm{ml})$ were added to $1.15 \mathrm{ml}$ of ATP-regenerating buffer consisting of $95 \mathrm{~mm} \mathrm{KCl}, 20 \mathrm{~mm}$ potassium 3-( $N$-morpholino) propanesulfonic acid, $7.5 \mathrm{~mm}$ sodium pyrophosphate, $250 \mu \mathrm{M}$ APIII, $12 \mu \mathrm{g} / \mathrm{ml}$ creatine phosphokinase, $5 \mu \mathrm{M}$ phosphocreatine, and $1 \mathrm{~mm} \mathrm{MgATP}, \mathrm{pH} 7.0$ (final volume of $1.2 \mathrm{ml}$ ) (Palade, 1987). Ruthenium red $(10 \mu \mathrm{M})$ was added to 
the assay medium to fully inhibit RyR activation during measurement of rates of $\mathrm{Ca}^{2+}$ uptake (Feng et al., 1999). Transport assays were performed at $37^{\circ} \mathrm{C}$ in temperature-controlled cuvettes with constant stirring. SR vesicles were loaded with a single addition of $80 \mathrm{nmol}$ of $\mathrm{CaCl}_{2}$ that constituted $\sim 80 \%$ of their loading capacity. The initial rate of $\mathrm{Ca}^{2+}$ accumulation was measured by monitoring extravesicular changes in free $\mathrm{Ca}^{2+}$ by subtracting the absorbance of APIII at $790 \mathrm{~nm}$ from absorbance at $710 \mathrm{~nm}$ at $2-4 \mathrm{sec}$ intervals. At the end of each experiment, the total intravesicular $\mathrm{Ca}^{2+}$ was determined by addition of $3 \mu \mathrm{M}$ of the $\mathrm{Ca}^{2+}$ ionophore $\mathrm{A} 23187$, and the absorbance signals were calibrated by addition of $12 \mathrm{nmol}$ or $24 \mathrm{nmol}$ of $\mathrm{CaCl}_{2}$ from a National Bureau of Standard stock solution. The actions of $\mathrm{XeC}(50 \mu \mathrm{M})$ were studied by adding the compound $15-60 \mathrm{~min}$ before initiating $\mathrm{Ca}^{2+}$ loading. $\mathrm{XeC}$ at the concentrations used in this study did not interfere with the absorbance properties or calibration of the APIII dye. Each experimental condition was repeated 3-5 times, and the data are shown as mean $\pm \mathrm{SD}$.

Chemicals. Methacholine (MeCh), 2-methyl-thio ATP (2-MeSATP), DMPX, A23187, APIII, ruthenium red, ryanodine, and thapsigargin were purchased from Sigma (St. Louis, MO) and Research Biochemicals (Natick, MA). 2-aminoethoxydiphenylborane (2-APB) was from Tocris (St. Louis, MO); XeC and U73122 were from Calbiochem (San Diego, CA). $\mathrm{XeC}$ was also provided by T. F. Molinski (University of California, Davis, CA).

\section{RESULTS}

\section{OP process dimensions}

OPs in culture show a bipolar morphology, with processes extending $>100 \mu \mathrm{m}$ from the cell soma (Fig. 1A). Processes were cylindrical, averaging 2-3 $\mu \mathrm{m}$ in diameter in every plane (Fig. $1 B-D)$. For all experiments, a scan line was oriented along a straight section of an OP process. The cell soma was approximately threefold thicker and wider than the processes. Average soma width, measured perpendicular to process extension, was $8.12 \pm 0.46 \mu \mathrm{m}(n=3)$; thickness averaged $11.16 \pm 0.039 \mu \mathrm{m}$ $(n=4)$ (Fig. $1 D)$.

\section{Localization of RyR and $\mathrm{IP}_{3} R$ clusters}

$\mathrm{IP}_{3} \mathrm{R}$ and $\mathrm{RyR}$ isoforms have distinct single channel kinetics. Because the isoform or isoforms expressed may determine the dynamics of local events and $\mathrm{Ca}^{2+}$ waves (Hagar et al., 1998; Conklin et al., 2000), we investigated which subtypes were expressed in OPs. We found specific immunoreactivity to $\mathrm{IP}_{3} \mathrm{R} 2$ and RyR3 antibodies (Fig. 2). OPs did not show specific staining with the antibody $34 \mathrm{C}$, which recognizes type 1 and 2 RyRs. In parallel experiments this antibody reacted strongly in skeletal muscle cells (data not shown). OPs did not show immunoreactivity to antibodies for $\mathrm{IP}_{3} \mathrm{R} 1$ or $\mathrm{IP}_{3} \mathrm{R} 3$ (data not shown).

Distinct patchy immunofluorescence for $\mathrm{IP}_{3} \mathrm{R} 2$ and $\mathrm{RyR} 3$ was seen along OP processes. RyR3 patches appeared larger then $\mathrm{IP}_{3} \mathrm{R} 2$ patches. In many cases, $\mathrm{IP}_{3} \mathrm{Rs}$ and RyRs were colocalized (Fig. $2 B$ ). Although $\mathrm{IP}_{3} \mathrm{R} 2$ was usually expressed in patches with RyR3, $\mathrm{IP}_{3} \mathrm{R} 2$ immunoreactivity often was seen without RyR3 (Fig. 2C). The distribution pattern suggests overlapping but distinct roles for these $\mathrm{Ca}^{2+}$ release channels so that in some regions $\mathrm{IP}_{3} \mathrm{Rs}$ and RyRs may interact, whereas in other areas $\mathrm{IP}_{3} \mathrm{Rs}$ may act independently.

\section{Local $\mathrm{Ca}^{2+}$ release in OP processes}

The first specific goal of our study was to determine whether OPs manifested localized $\mathrm{Ca}^{2+}$ release events similar to sparks or puffs. Sparks represent $\mathrm{Ca}^{2+}$ release from clusters of RyRs and show a characteristic time $(30 \mathrm{msec})$ and space $(2 \mu \mathrm{m})$ profile (Cheng et al., 1993). Puffs are generated by release through $\mathrm{IP}_{3} \mathrm{Rs}$ and have an average duration of $100 \mathrm{msec}$ and width of $2-3 \mu \mathrm{m}$ (Callamaras and Parker, 1999). Local release events in neurons may involve both $\mathrm{IP}_{3} \mathrm{Rs}$ and RyRs and are significantly larger
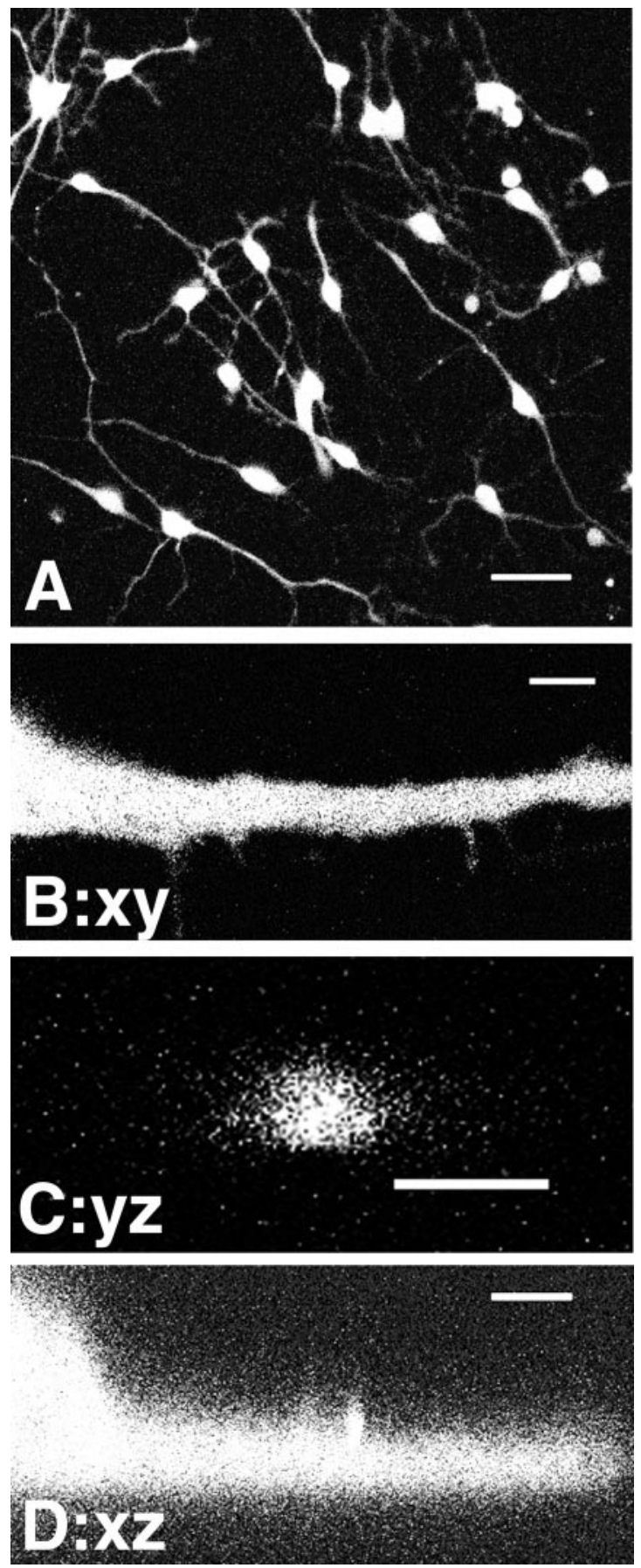

Figure 1. OP process dimensions. OPs display long bipolar processes. $A$, A $40 \times$ field of view of fluo-4-loaded OPs at typical density. Scale bar, 40 $\mu \mathrm{m}$. The perfusion pipette was positioned just outside of the field of view, and the pipette diameter was the size of the field. $B$, A process of a typical OP shown at $8 \times$ zoom. Scale bar, $4 \mu \mathrm{m}$. Average process width in the $x y$ plane was $2.42 \pm 0.02 \mu \mathrm{m}(n=11)$. $C$, To determine cross-sectional thickness, processes were scanned in the $y z$ plane. Process thickness averaged $3.124 \pm 0.23 \mu \mathrm{m}(n=3)$. Scale bar, $4 \mu \mathrm{m}$. $D$, To determine uniformity of process thickness, processes were scanned in the $x z$ longitudinal plane. This image shows both the soma and process. Processes were typically $2.58 \pm 0.15-\mu \mathrm{m}$-thick along the scan line $(n=7)$. Scale bar, $4 \mu \mathrm{m}$.

than sparks or puffs, with a spatial spread of 5-6 $\mu \mathrm{m}$ and a duration close to $1 \mathrm{sec}$ (Koizumi et al., 1999).

Albeit infrequently, spontaneous local release events could be unequivocally resolved in OPs by high spatiotemporal resolution 

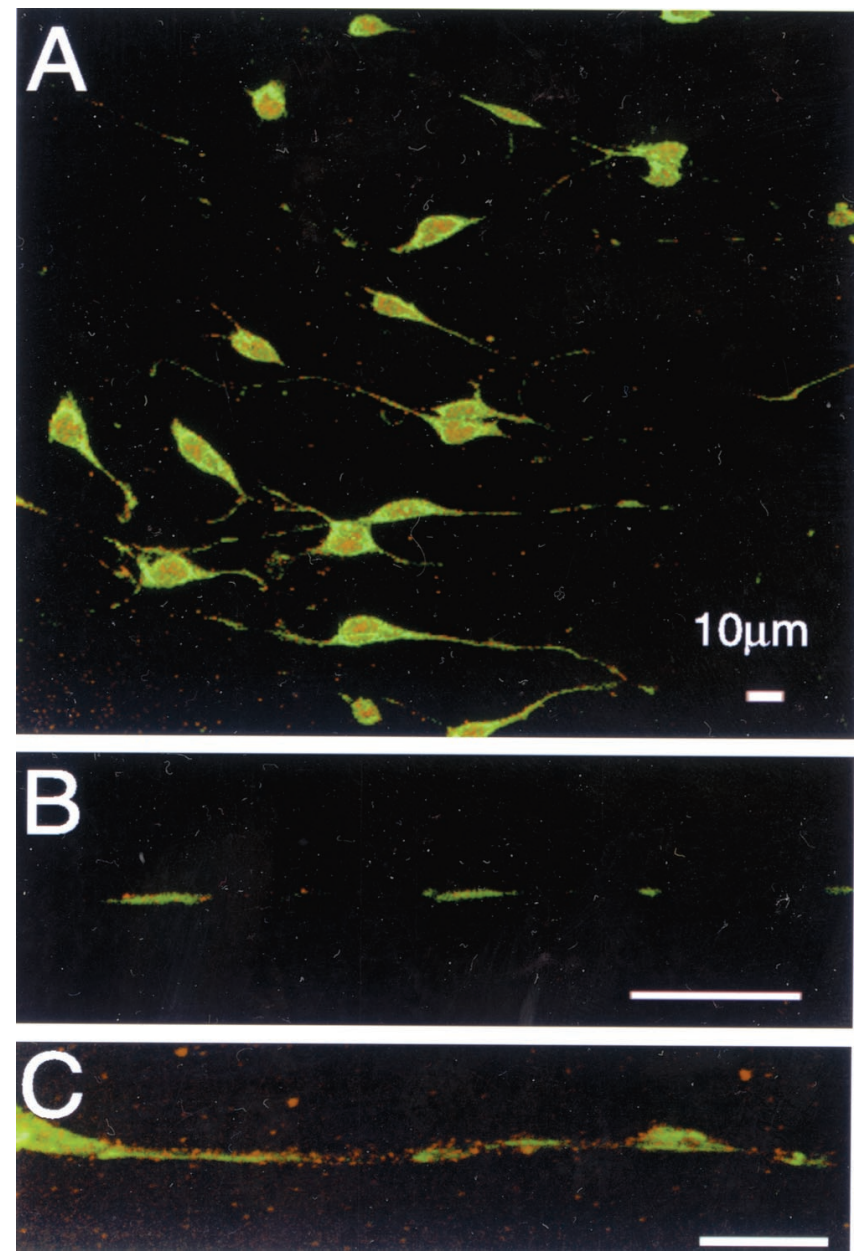

Figure 2. $\mathrm{IP}_{3} \mathrm{R} 2$ and RyR3 colocalized. Confocal images focused on $\mathrm{OP}$ processes show beaded pattern of expression $\mathrm{IP}_{3}$ Rs and RyRs. Scale bars, $10 \mu \mathrm{m}$ (for all panels). A, OPs soma and processes express RyR3 (green) and $\mathrm{IP}_{3} \mathrm{R} 2$ (red). Immunoreactivity for $\mathrm{IP}_{3} \mathrm{R} 2$ was strong throughout the cell, whereas RyR3 appeared to be excluded from the nuclear membrane area. Both receptors showed a patchy distribution along processes. $B, \mathrm{~A}$ process from $A$ enlarged to show frequent colocalization of $\mathrm{IP}_{3} \mathrm{R} 2$ and RyR3. $C$, Another process from $A$ enlarged to show $\mathrm{IP}_{3} \mathrm{R} 2$ and $\mathrm{RyR}$ are not always colocalized. In this process, $\mathrm{IP}_{3} \mathrm{R} 2$ is expressed in small patches along the entire process. RyR expression is limited to larger patches that do not completely overlap with $\mathrm{IP}_{3} \mathrm{R} 2$.

line scan imaging. A typical example of a spontaneous event is shown in Figure 3. Events were measured after manually identifying regions of interest within a line scan image. Events had a characteristic sharp onset (Fig. $3 D$ ), lateral propagation (Fig. 3A), and exponential decay to baseline (Fig. 3D).

We observed nine spontaneous events in three of 51 OP processes scanned under basal conditions. None of these events triggered a wave. These events exhibited an amplitude of $1.10 \pm$ $0.02 F / F_{\text {o }}$, a FWHM of $2.37 \pm 0.42 \mu \mathrm{m}$, and a FDHM of $67.60 \pm$ 16.03 msec. Local release events resolved in OPs thus fall between "classical" $\mathrm{Ca}^{2+}$ sparks and puffs and are significantly smaller than the elementary release events described in neurons. Because RyRs and $\mathrm{IP}_{3} \mathrm{Rs}$ in OPs are largely quiescent, we studied local release events using specific $\mathrm{IP}_{3} \mathrm{R}$ and RyR agonists.

\section{$\mathrm{Ca}^{2+}$ sparks evoked by a caffeine analog}

Local $\mathrm{Ca}^{2+}$ release events could be evoked by applying the caffeine analog DMPX (1-2.5 mM; $n=96$ events in 27 cells).
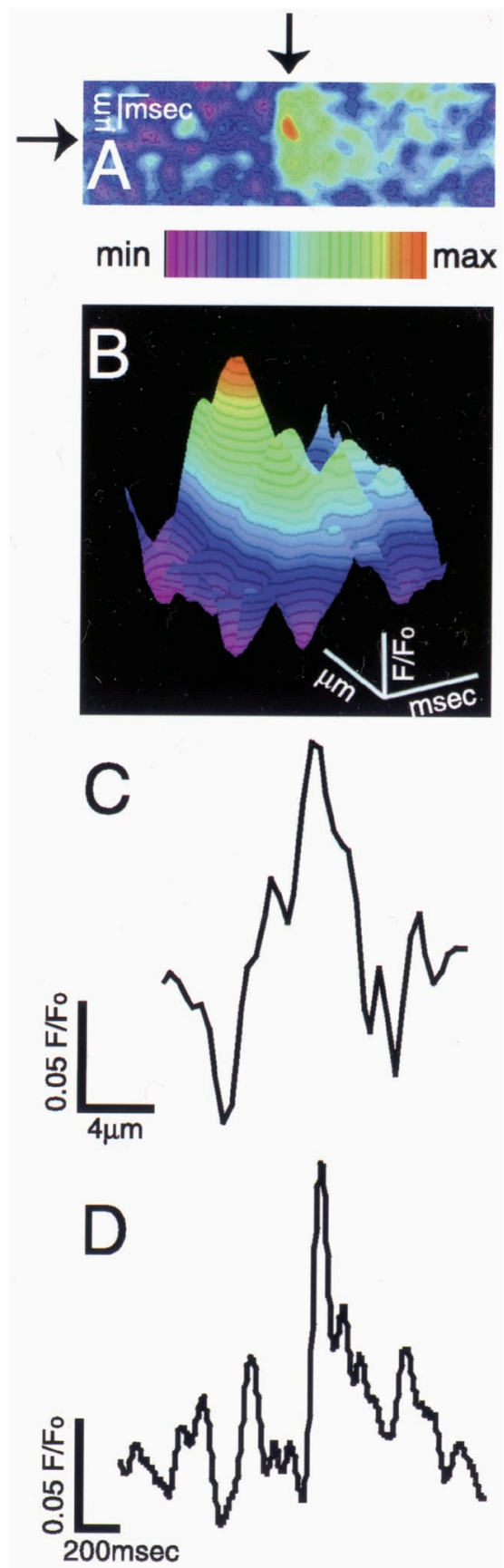

Figure 3. Elementary $\mathrm{Ca}^{2+}$ release events under basal conditions. Spontaneous events were observed in OPs ( 3 of 51 cells). $A$, Line scan of a typical spontaneous event. Time is displayed along the $x$-axis, and distance is displayed along the process along the $y$-axis. Calibration: 200 msec, $4 \mu \mathrm{m}$. The full range color scale used for all images is shown below $A$. $B$, Three-dimensional representation of the event shown in $A$. Average intensity of spontaneous events was $1.10 \pm 0.02 F / F_{\mathrm{o}}(n=9)$. Calibration: $200 \mathrm{msec}, 4 \mu \mathrm{m}, 0.05 F / F_{\mathrm{o}}$. $C$, A line plot through the spatial plane ( $A$, vertical arrow) showing event width. Calibration: $4 \mu \mathrm{m}, 0.05 F / F_{\mathrm{o}} . D$, A line plot through the temporal plane $(A$, horizontal arrow) showing event duration. Event onset is rapid, occurring in $<30 \mathrm{msec}$. Calibration: 200 msec, $0.05 F / F_{\mathrm{o}}$.

DMPX applied in standard perfusion medium elicited events with a characteristic spatial profile (Fig. 4). Events were significantly larger in amplitude than spontaneous events $\left(F / F_{\mathrm{o}}=\right.$ $1.31 \pm 0.009 ; p<0.0001)$, but were otherwise indistinguishable with an FWHM of $2.37 \pm 0.18 \mu \mathrm{m}$ and an FDHM of $66.35 \pm 6.8$ 

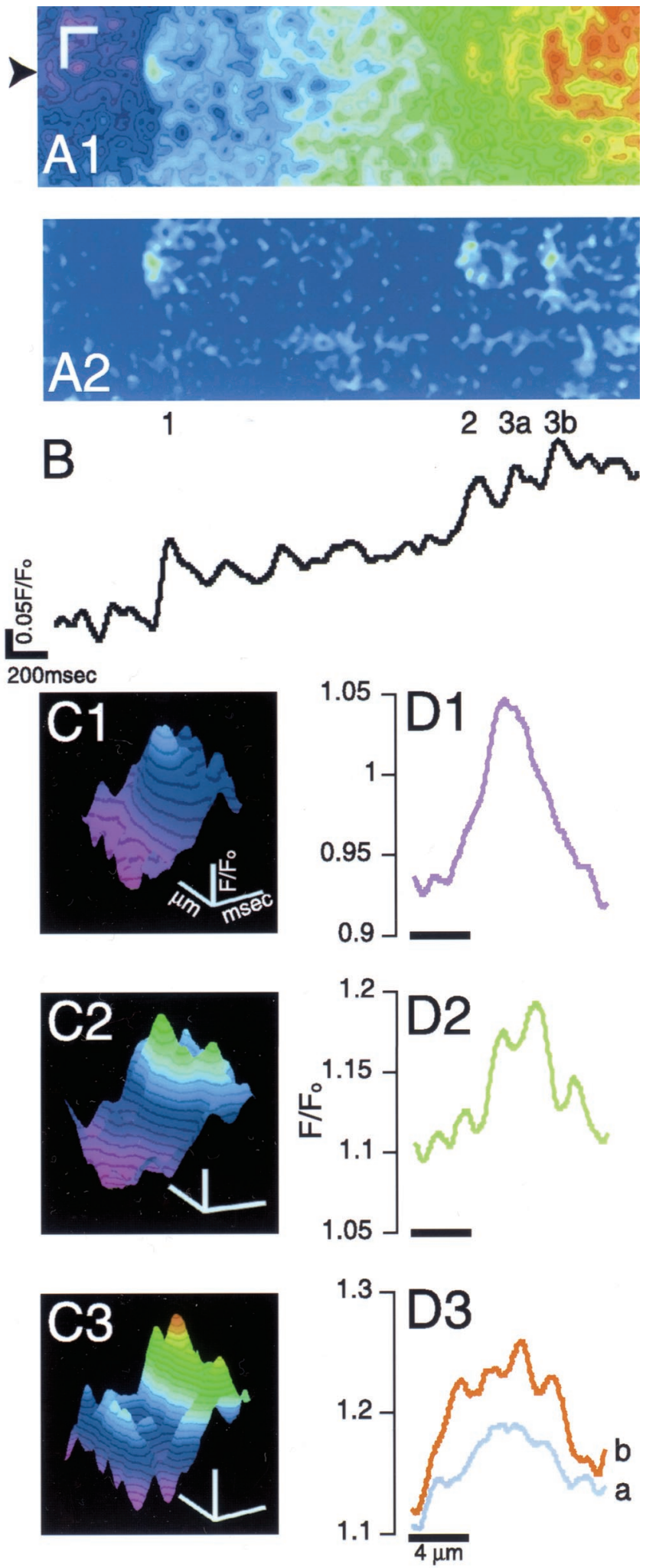

Figure 4. Caffeine analog evokes elementary events. DMPX (2 mM) evokes repeating elementary events in OPs processes. A1, Line scan image showing DMPX-evoked events. Calibration: $200 \mathrm{msec}, 4 \mu \mathrm{m}$. $A 2$, A high-pass-filtered image of $A 1$. Image was created by subtracting a $100 \times$ 100 smoothed image from $A 1$. Three individual events are clearly seen in this filtered image. All three events initiate at precisely the same location; there is a $2.7 \mathrm{sec}$ interval between events 1 and 2 and $0.7 \mathrm{sec}$ between events 2 and $3 \mathrm{~b}$. $B$, A line plot drawn across $A 1$, where indicated by the arrow. All events show a rapid time-to-peak. Calibration: $200 \mathrm{msec}, 0.05$ msec. DMPX events frequently repeated at the same site and occurred concurrently with an increasing $\left[\mathrm{Ca}^{2+}\right]_{\mathrm{i}}$ (Fig. 4A). In the accompanying high-pass-filtered image (Fig. $4 B$ ), only the event areas with the highest rate of change are shown, i.e., the centers of mass. All events had a center of mass at exactly the same location, indicating that the same receptor or receptor cluster was activated in each repeat. As ambient $\left[\mathrm{Ca}^{2+}\right]_{\mathrm{i}}$ rose, event morphology increased in complexity (Fig. 4C). At lower $\left[\mathrm{Ca}^{2+}\right]_{\mathrm{i}}$, event width was described by an arc with a single peak (Fig. 4D1); as ambient $\left[\mathrm{Ca}^{2+}\right]_{\mathrm{i}}$ increased, event width profiles showed multiple peaks (Fig. 4D2) and events became wider (Fig. $4 D 3$ ), as if neighboring release units had been recruited.

\section{$\mathrm{Ca}^{2+}$ puffs evoked by phospholipase $\mathrm{C} / \mathrm{IP}_{3}$-linked agonists}

We could evoke local events reliably using the phospholipase $\mathrm{C}$ (PLC)/ $\mathrm{IP}_{3}$-linked muscarinic agonist $\mathrm{MeCh}(3 \mu \mathrm{M} ; n=64$ events in 34 cells) or 2-MeSATP ( $1 \mu \mathrm{M} ; n=12$ events in 7 cells). Events occurred within a second of agonist application, and they were frequently repeated in the same location (Fig. $5 A$, top). By highpass filtering the line scan image, we were able to show that the first event had three centers of mass, one of which was also found in the subsequent event (Fig. $5 A$, bottom). The same release sites were thus involved in both events.

$\mathrm{MeCh}$ and DMPX-evoked local events showed kinetic differences (Table 1). MeCh events showed a larger amplitude and smaller spatial spread than DMPX events. MeCh event amplitudes show a bimodal distribution (Fig. $5 B$, top), with an average of $1.43 \pm 0.02 F / F_{\mathrm{o}}$, significantly larger than DMPX events $(p<$ 0.0001). Conversely, the distribution of $\mathrm{MeCh}$ event widths was compressed compared with DMPX events (Fig. 5B, middle), with a significantly smaller width profile $(1.75 \pm 0.09 \mu \mathrm{m} ; p=0.0028)$. Finally, MeCh event durations showed a modal distribution with peaks at 40 and $80 \mathrm{msec}$ (Fig. 5C, bottom). However, there was no significant difference between the average FDHM of $\mathrm{MeCh}$ events $(69.55 \pm 5.8 \mathrm{msec})$ and DMPX events. These distinct morphological profiles suggest that MeCh- and DMPX-evoked events were attributable to opening of different classes of $\mathrm{Ca}^{2+}$ release channels.

The morphology of local events was also affected by reducing agonist concentration (Table 1). Event amplitude was significantly lower in OP processes treated with $30 \mathrm{~nm} \mathrm{MeCh}(1.32 \pm$ $\left.0.02 F / F_{\text {o }} ; n=45 ; p=0.0006\right)$ compared with $3 \mu \mathrm{M} \mathrm{MeCh}$. Time to peak $\left(T_{\text {peak }}\right)$ was also significantly slower in cells treated with $30 \mathrm{~nm} \mathrm{MeCh}(30 \mathrm{~nm}: 103.0 \pm 9.8 \mathrm{msec}, n=44 ; 3 \mu \mathrm{M}: 74.3 \pm 5.6$ msec, $n=63$; $p=0.0130)$. FWHM and FDHM were not significantly affected. Clearly activation of local $\mathrm{Ca}^{2+}$ release is linked to agonist concentration: events were faster and higher amplitude at higher $\mathrm{MeCh}$ concentrations. However, without pharmacological characterization, we cannot exclude that $\mathrm{MeCh}$ and DMPX are activating different sized clusters of the same release channel type.

\section{$\leftarrow$}

$F / F_{\mathrm{o}}$. $C$, Individual surface plots of the numbered events in $A$. Same peak color is used as in $A$, but baseline is stretched so as to use the entire color table range. Event morphology appears to increase in complexity with increasing $\left[\mathrm{Ca}^{2+}\right]_{\mathrm{i}}$. For example, the event depicted in $C 1$ shows a conical profile, the event in $C 2$ shows increased width, and the event in $C 3$ is a doublet. Calibration: $200 \mathrm{msec}, 4 \mu \mathrm{m}, 0.05 F / F_{\mathrm{o}} . D$, Corresponding width plots for the numbered events in $A 2$. As ambient $\left[\mathrm{Ca}^{2+}\right]_{\mathrm{i}}$ increases, event width increases. Calibration: $4 \mu \mathrm{m}, 0.05 F / F_{\mathrm{o}}$. 

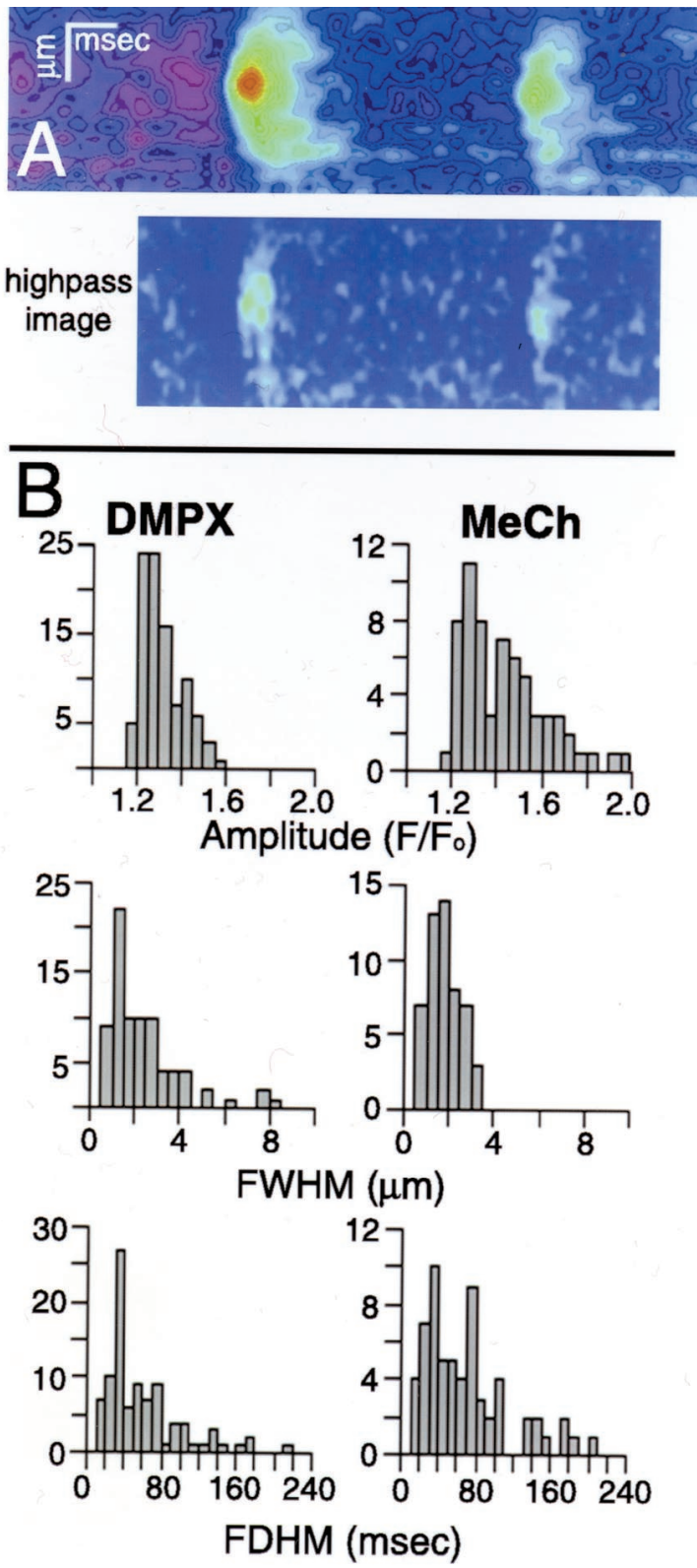

Figure 5. Elementary events evoked by $\mathrm{PLC} / \mathrm{IP}_{3}$-linked agonist. Events were evoked reliably by $\mathrm{MeCh}(3 \mu \mathrm{M} ; n=64)$. A, Top, Line scan image of local events; in this typical cell, an event repeats at the same location. Calibration: $200 \mathrm{msec}, 4 \mu \mathrm{m}$. Bottom, To determine center of mass, the line scan image was high-pass-filtered, as described in the legend to Figure 3. The first event has three centers of mass separated laterally by $1.6-2.0$ $\mu \mathrm{m}$. The second event has two centers of mass separated laterally by 2.0 $\mu \mathrm{m}$. The onset of the second event follows the onset of the first event by $1.66 \mathrm{sec}$, with a lateral displacement of $1.6 \mu \mathrm{m} . B$, Events evoked by $\mathrm{MeCh}$ and DMPX showed significantly different temporal and spatial profiles. Binned events illustrate distributions of amplitude (top), width (middle), and duration (bottom).

\section{Which $\mathrm{Ca}^{2+}$ release channels are mediating local events?}

To ascertain which release channels are involved in cytosolic $\mathrm{Ca}^{2+}$ rises in OPs, we began by testing the effects of release channel antagonists on global $\left[\mathrm{Ca}^{2+}\right]_{\mathrm{i}}$ rises using wide-angle microscopy. Experiments in fluo-3-loaded OPs showed that global $\mathrm{Ca}^{2+}$ rises evoked by $100 \mathrm{nM} \mathrm{MeCh}$ were abolished by the PLC inhibitor U73122 (20 $\mu \mathrm{M})$, as well as by the $\mathrm{IP}_{3} \mathrm{R}$ antagonists
Table 1. Unitary properties of elementary $\mathrm{Ca}^{2+}$ release events in OP cells

\begin{tabular}{lclll} 
& $\begin{array}{l}\text { Number } \\
\text { of events }\end{array}$ & $F / F_{\mathrm{o}}$ & $\begin{array}{l}\text { FWHM } \\
(\mu \mathrm{m})\end{array}$ & $\begin{array}{l}\text { FDHM } \\
(\mathrm{msec})\end{array}$ \\
\hline Spontaneous & 9 & $1.10 \pm 0.02$ & $2.37 \pm 0.42$ & $67.6 \pm 16.0$ \\
DMPX $(1-2.5 \mathrm{mM})$ & 96 & $1.31 \pm 0.01$ & $2.37 \pm 0.18$ & $66.4 \pm 6.8$ \\
MeCh $(3 \mu \mathrm{M})$ & 64 & $1.43 \pm 0.02$ & $1.75 \pm 0.09$ & $69.5 \pm 5.8$ \\
MeCh $(30 \mathrm{nM})$ & 5 & $1.33 \pm 0.02$ & $2.12 \pm 0.20$ & $70.5 \pm 7.0$
\end{tabular}

$\mathrm{XeC}(20 \mu \mathrm{M})$ and 2-APB $(100 \mu \mathrm{M})$ (Fig. 6A1). At higher concentrations of agonist, these antagonists were less effective at inhibiting global $\mathrm{Ca}^{2+}$ responses, as if the $\mathrm{MeCh}$ dose-response relationship had shifted rightward. Only U73122 decreased the number of cells responding (\% responders) to $3 \mu \mathrm{M} \mathrm{MeCh}$. However, the peak amplitude of $\mathrm{MeCh}$-evoked global $\mathrm{Ca}^{2+}$ rises was significantly decreased in cells treated with $\mathrm{XeC}(p<0.0001$; $n=44)$ or 2 -APB ( $p=0.0051 ; n=316)$ (Fig. 6A2). Incubation with ryanodine up to $300 \mu \mathrm{M}$ did not block MeCh $(3 \mu \mathrm{M})$-evoked global rises (MeCh: 205 of 215 cells respond; $\mathrm{MeCh}+$ ryanodine: 183 of 215 cells respond).

Local $\mathrm{Ca}^{2+}$ release was similarly affected by $\mathrm{IP}_{3} \mathrm{R}$ antagonists. In line scan experiments, $\mathrm{XeC}$ and 2-APB blocked $\mathrm{MeCh}$ (30 $\mathrm{nm}$ )-evoked events in $\sim 30 \%$ of OPs (Table 2). In the XeC-treated cells that did respond to $\mathrm{MeCh}$, events were of significantly smaller amplitude than in untreated cells $(+\mathrm{XeC}: 1.27 \pm 0.06$, $n=51 ; p=0.0268$ ) (Fig. 6B1). The effects of $\mathrm{XeC}$ on $\mathrm{Ca}^{2+}$ response amplitude were not caused by blockade of SERCAdriven ATPase activity (Fig. $7 A$ ) or to general inhibition of $\mathrm{Ca}^{2+}$ uptake (Fig. $7 B$ ). XeC, up to a concentration of $100 \mu \mathrm{M}$, did not inhibit $\mathrm{Ca}^{2+}$-ATPase activity and did not block $\mathrm{Ca}^{2+}$ uptake into isolated sarcoplasmic reticulum vesicles (Fig. 7). Finally, ryanodine did not affect the number of cells showing MeCh-evoked local events or the number of events per cell (Table 2). Thus, our data show that $\mathrm{Ca}^{2+}$ release by $\mathrm{IP}_{3} \mathrm{Rs}$ and not RyRs likely mediates local events generated by $\mathrm{MeCh}$.

DMPX (2 mM) evoked subcellular but not global $\mathrm{Ca}^{2+}$ rises that were too small to be resolved using wide-angle microscopy $(n=280)$, so we studied local DMPX $\mathrm{Ca}^{2+}$ release using line scan analysis. Ryanodine and both $\mathrm{XeC}$ and 2-APB inhibited the probability of DMPX-evoked local events (Table 2). Ryanodine treatment alone did not evoke events. Ryanodine and $\mathrm{XeC}$ decreased both the number of cells that responded to DMPX and the number of events per cell, whereas 2-APB decreased only the number of responding cells. The fact that $\mathrm{XeC}$ and 2-APB influence DMPX-evoked events may indicate either that there is interplay between $\mathrm{IP}_{3} \mathrm{Rs}$ and RyRs in DMPX-evoked $\mathrm{Ca}^{2+}$ release, or that these two inhibitors act on both receptor types. Although XeC has low affinity for RyRs (Gafni et al., 1997), 2-APB has no effect on RyR function (Maruyama et al., 1997). Thus, our data suggest that DMPX-events are mediated by RyRs, but $\mathrm{IP}_{3} \mathrm{Rs}$ contribute to the signal. It is possible that RyRmediated $\mathrm{Ca}^{2+}$ release activates PLC and causes $\mathrm{IP}_{3}$ generation in the local cellular domain.

\section{Cross talk between $I_{3}$ Rs and RyRs}

Although $\mathrm{MeCh}$ events were mediated by $\mathrm{IP}_{3} \mathrm{Rs}$, they were modulated by RyRs. In line scan experiments, the probability of $\mathrm{MeCh}$ (30 nM)-evoked events was not affected by ryanodine (Table 2), but the amplitude was significantly increased (control: $1.31 \pm 0.01 F / F_{\mathrm{o}}, n=61$; +ryanodine: $1.43 \pm 0.04 F / F_{\mathrm{o}}, n=18$; 

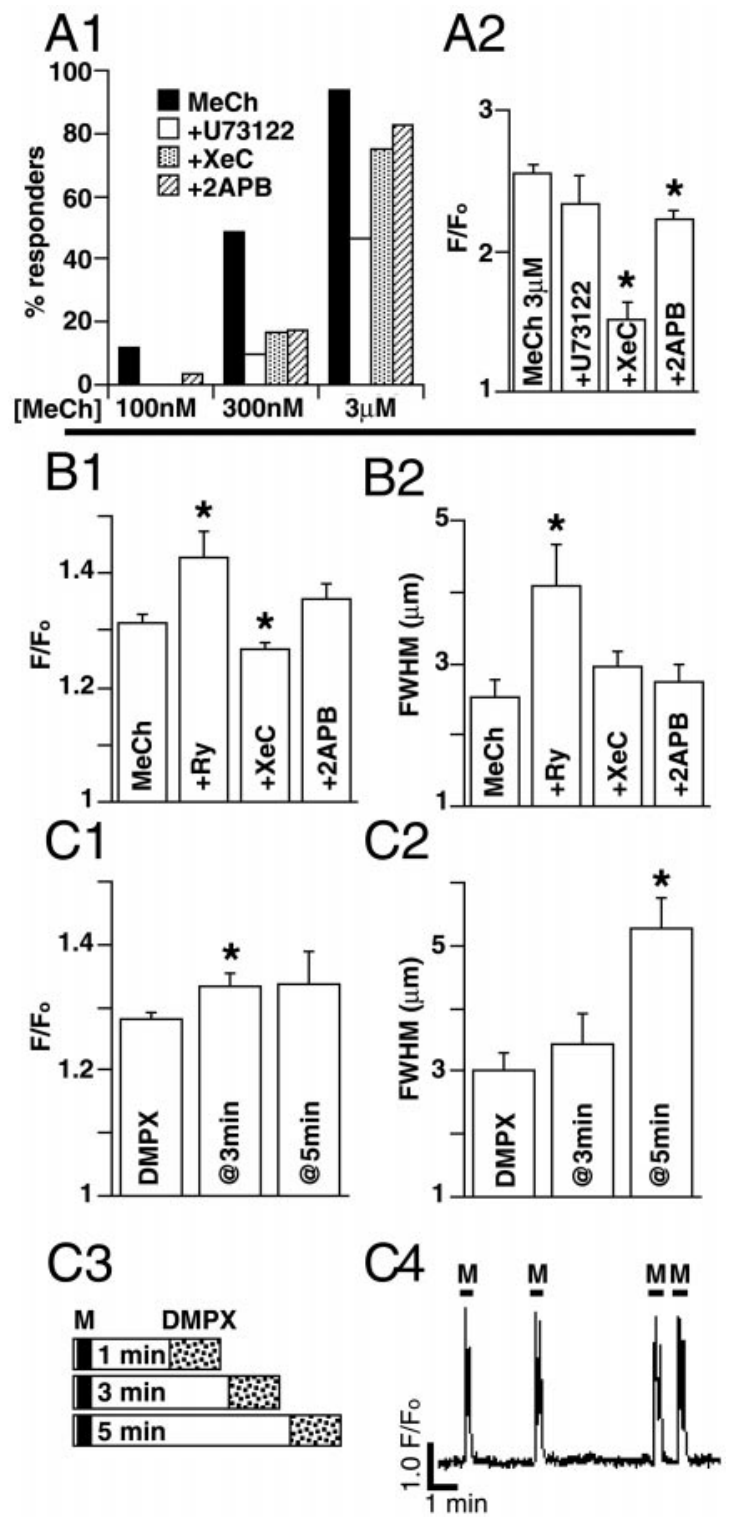

Figure 6. Cross talk between $\mathrm{IP}_{3} \mathrm{R}$ and RyR. $A$, MeCh-evoked global $\left[\mathrm{Ca}^{2+}\right]_{\mathrm{i}}$ rises were mediated by $\mathrm{IP}_{3} \mathrm{Rs}$ in OPs. $\mathrm{Ca}^{2+}$ rises were measured in fluo-3-loaded OPs using wide-angle microscopy at a collection speed of 1 frame/sec. Responders were cells that showed a fluorescence rise $>10 \%$ over the prestimulus baseline level. A1, At lower concentrations of agonist, agents that inhibit PLC or block $\mathrm{IP}_{3} \mathrm{Rs}$ abolished evoked $\mathrm{Ca}^{2+}$ responses. Cells were pretreated with U73122 $(10 \mu \mathrm{M})$ or XeC $(20 \mu \mathrm{M})$ for 20 min or perfused with 2-APB for 5 min before testing with MeCh. A2, Cells responding to $3 \mu \mathrm{M} \mathrm{MeCh}$ were inhibited by $\mathrm{IP}_{3} \mathrm{R}$ antagonists. The plot shows that peak amplitude of global $\mathrm{Ca}^{2+}$ responses was significantly inhibited by $\mathrm{XeC}$ and 2-APB. $B, C$, Elementary events were modulated by agents that block $\mathrm{IP}_{3}$ Rs or RyRs. Elementary events evoked by $30 \mathrm{nM}$ $\mathrm{MeCh}$ or $2 \mathrm{~mm}$ DMPX were recorded in fluo-4-loaded OP processes using line scan confocal microscopy. B1, Ryanodine $(10 \mu \mathrm{M})$ enhanced and $\mathrm{XeC}$ reduced the amplitude of $\mathrm{MeCh}(30 \mathrm{~nm})$-evoked events. B2, Ryanodine also enhanced the width of MeCh-evoked events. $C$, DMPX events were modulated by pretreatment with $\mathrm{MeCh}(3 \mu \mathrm{M})$. C1, Three minutes after pulsing with MeCh, DMPX events showed a higher amplitude $(p=0.0238 ; n=24)$. $C 2$, Five minutes after MeCh, DMPX event width was increased ( $p=0.0005 ; n=17)$. $C 3$, A diagram of the three $\mathrm{MeCh}$ prepulse protocols. Cells were treated with $\mathrm{MeCh}(M)$ for $15 \mathrm{sec}$, then washed for 1,3 , or 5 min (open bar) before testing with DMPX (stippled bar). C4, $\mathrm{Ca}^{2+}$ stores were not depleted by the $\mathrm{MeCh}$ pulse, as shown in this representative trace from a wide-angle microscopy experiment $(n=440)$. MeCh applied for $15 \mathrm{sec}$ (black bars) at 3, 5, and $1 \mathrm{~min}$ intervals evoked repeatable amplitude $\mathrm{Ca}^{2+}$ responses.

\begin{tabular}{lcl}
\hline \multicolumn{2}{l}{ Table 2. RyRs and IP3Rs mediate elementary events } \\
Treatment & $\%$ Nonresponders $(n)$ & Events per cell \\
\hline MeCh $(30 \mathrm{nM})$ & $6.25 \%(1 / 16)$ & 4.0 \\
MeCh + ryanodine & $0(0 / 5)$ & 3.6 \\
MeCh + XeC & $28.6(4 / 14)$ & 3.6 \\
MeCh + 2-APB & $33.3(4 / 12)$ & 6.5 \\
DMPX (2 mM) & $8.3(1 / 12)$ & 4.0 \\
DMPX + ryanodine & $70.8(17 / 24)$ & 1.4 \\
DMPX + XeC & $66.7(2 / 3)$ & 1.0 \\
DMPX + 2-APB & $57.1(4 / 7)$ & 4.6
\end{tabular}

$p=0.0227$ ) (Fig. 6B1). In addition, events were wider (control: $2.53 \pm 0.26 \mu \mathrm{m}$; +ryanodine: $4.07 \pm 0.6 \mu \mathrm{m} ; p=0.0279$ ) (Fig. $6 B 2)$ than in control cells. RyRs colocalized with $\mathrm{IP}_{3} \mathrm{Rs}$ in OP processes contribute to event size but not frequency.

$\mathrm{MeCh}$ pretreatment potentiated subsequent DMPX-evoked local events (Fig. 6C). OPs were stimulated with $\mathrm{MeCh}(3 \mu \mathrm{M})$ for $15 \mathrm{sec}$, then tested with DMPX (2 mM) after 1, 3, or 5 min (Fig. $6 C 3)$. After $1 \mathrm{~min}$, two of five cells treated with DMPX showed four events, many fewer then in control cells. After 3 min, DMPX responsiveness was restored: five of five cells showed 24 events. These events had a higher amplitude than control events (preMeCh: $1.28 \pm 0.01 F / F_{\mathrm{o}}, n=48$; post-MeCh: $1.33 \pm 0.02 F / F_{\mathrm{o}}$, $n=24 ; p=0.0238$ ) (Fig. 6C1). After $5 \mathrm{~min}$, DMPX events were significantly wider than in control cells (pre-MeCh: $3.02 \pm 0.28$ $\mu \mathrm{m}, n=48$; post-MeCh: $5.26 \pm 0.5 \mu \mathrm{m}, n=17$; $p=0.0005$ ) (Fig. $6 C 2)$. The decreased responsiveness to DMPX at the $1 \mathrm{~min}$ interval was not caused by $\mathrm{Ca}^{2+}$ stores being emptied by $\mathrm{MeCh}$. As shown in Figure $6 \mathrm{C} 4$, MeCh evoked repeatable $\mathrm{Ca}^{2+}$ rises whether applied at an interval of 3,5 , or 1 min. Together, these data show that previous stimulation of $\mathrm{IP}_{3} \mathrm{Rs}$ enhances activity of RyRs over several minutes and provide evidence for significant cross talk between $\mathrm{IP}_{3} \mathrm{Rs}$ and RyRs.

\section{$\mathrm{Ca}^{2+}$ sparks, macrosparks, and propagating $\mathrm{Ca}^{2+}$ waves: hierarchical $\mathbf{C a}^{2+}$ signaling $D M P X$-evoked spark repeats}

Local events were initiated with a $10 \mathrm{sec}$ latency after the onset of DMPX (1-2.5 mM) application. Events continued to fire as long as the agonist was applied (up to $2 \mathrm{~min}$ ). Events repeating in the same location were seen frequently. Often, repeats terminated in a larger but spatially restricted burst of $\mathrm{Ca}^{2+}$, but similar to spontaneous events DMPX did not trigger global $\mathrm{Ca}^{2+}$ waves (Fig. 8A). We measured 23 separate repeating sparks in 13 cells. There was a distinct change in size between the first and last spark: the amplitude increased $1.51 \pm 0.13$-fold, whereas the FDHM increased $5.61 \pm 1.9$-fold, and the FWHM increased $4.50 \pm 0.9$-fold. DMPX-evoked local events are not all-or-none phenomena. Events increased ambient $\left[\mathrm{Ca}^{2+}\right]_{\mathrm{i}}$ and facilitated $\mathrm{Ca}^{2+}$ release from neighboring release units, but stopped short of initiating a wave.

\section{MeCh-evoked events: elementary events evolve into macroevents and initiate a wave}

In OPs, the relationship between local and global $\mathrm{Ca}^{2+}$ signaling events was distinctly different for agents that target RyRs versus $\mathrm{IP}_{3}$ Rs. The $\mathrm{PLC} / \mathrm{IP}_{3}$-linked agonists $\mathrm{MeCh}(3 \mu \mathrm{M})$ and 2-MeSATP $(1 \mu \mathrm{M})$ evoked local events immediately ( $<1 \mathrm{sec})$ after application. Once initiated, events often repeated atop increasing ambient $\left[\mathrm{Ca}^{2+}\right]_{\mathrm{i}}$, then inevitably resulted in a global 

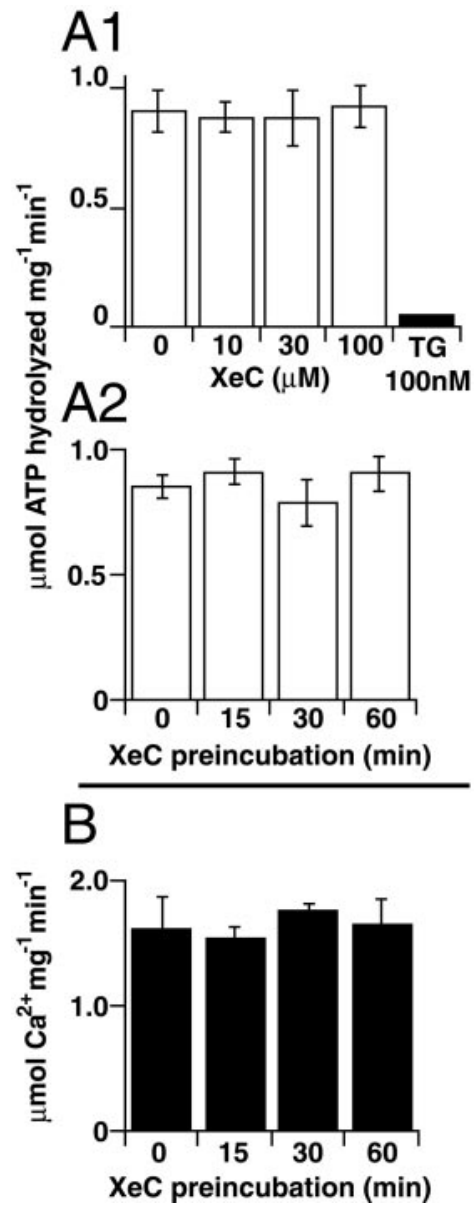

Figure 7. Xestospongin $\mathrm{C}$ does not inhibit SR/ER Ca ${ }^{2+}\left(\mathrm{Mg}^{2+}\right)$ ATPase nor alter the rate of $\mathrm{Ca}^{2+}$ accumulation. $\mathrm{XeC}(50-100 \mu \mathrm{M})$ has been reported to inhibit $\mathrm{Ca}^{2+}$ accumulation into SR-ER in permeabilized smooth muscle cells (De Smet et al., 1999). To directly test the action of XeC on SERCA pump activity, SR membrane vesicles enriched in SERCA1 were tested for dose- and time-dependent inhibition of thapsigargin $(T G)$-sensitive ATPase activity. $A 1, \mathrm{XeC}$ as high as $100 \mu \mathrm{M}$ preincubated for $10 \mathrm{~min}$ had negligible effect on TG-sensitive ATP hydrolysis. $A 2, \mathrm{XeC}(50 \mu \mathrm{M})$ preincubation for up to $60 \mathrm{~min}$ had no effect on TG-sensitive ATP hydrolysis. $B$, The initial rate of $\mathrm{Ca}^{2+}$ uptake into SR membrane vesicles was measured with the dye APIII as described in Materials and Methods. XeC $(50 \mu \mathrm{M})$ preincubated with SR for up to 60 min before uptake was initiated had negligible influence on $\mathrm{Ca}^{2+}$ uptake rate. This preparation was tested for potency toward blockade of $\mathrm{IP}_{3}$ induced $\mathrm{Ca}^{2+}$ release in isolated cerebellar microsomes $\left(\mathrm{IC}_{50}, 420 \mathrm{nM}\right.$; $\left.\mathrm{IC}_{95}, 1 \mu \mathrm{M}\right)$.

$\mathrm{Ca}^{2+}$ wave (MeCh: $81 \%$ of cells; 2-MeSATP: 100\%) (Fig. 8B). Local events were usually embedded in the wave onset (Fig. $8 B$, inset).

We found that $30 \mathrm{~nm} \mathrm{MeCh} \mathrm{never} \mathrm{evoked} \mathrm{a} \mathrm{global} \mathrm{Ca}^{2+}$ wave $(n=89)$, whereas $3 \mu \mathrm{M} \mathrm{MeCh}$ evoked a wave in 75 of 89 cells (Fig. 6A1). Using line scan confocal microscopy, we were able to measure subcellular $\left[\mathrm{Ca}^{2+}\right]_{\mathrm{i}}$ responses to $30 \mathrm{nM} \mathrm{MeCh}$, both local events and aborted waves (wavelets) (Fig. 8C). The onset slope of these wavelets (measured between 10 and $90 \%$ maximum) was significantly slower than for $3 \mu \mathrm{M} \mathrm{MeCh}(3 \mu \mathrm{M}$ : $0.14 \pm 0.02$ $\Delta F / \mathrm{msec}, n=8 ; 30 \mathrm{~nm}$ : $0.019 \pm 0.003 \Delta F / \mathrm{msec}, n=10 ; p=$ $0.0008)$. To obtain wave speed from line scan plots, time at $50 \%$ maximum intensity was plotted versus position along the process, and then line segments were fitted to these plots (Yagodin et al., 1994). As with onset slope, wave propagation speed was signifi-
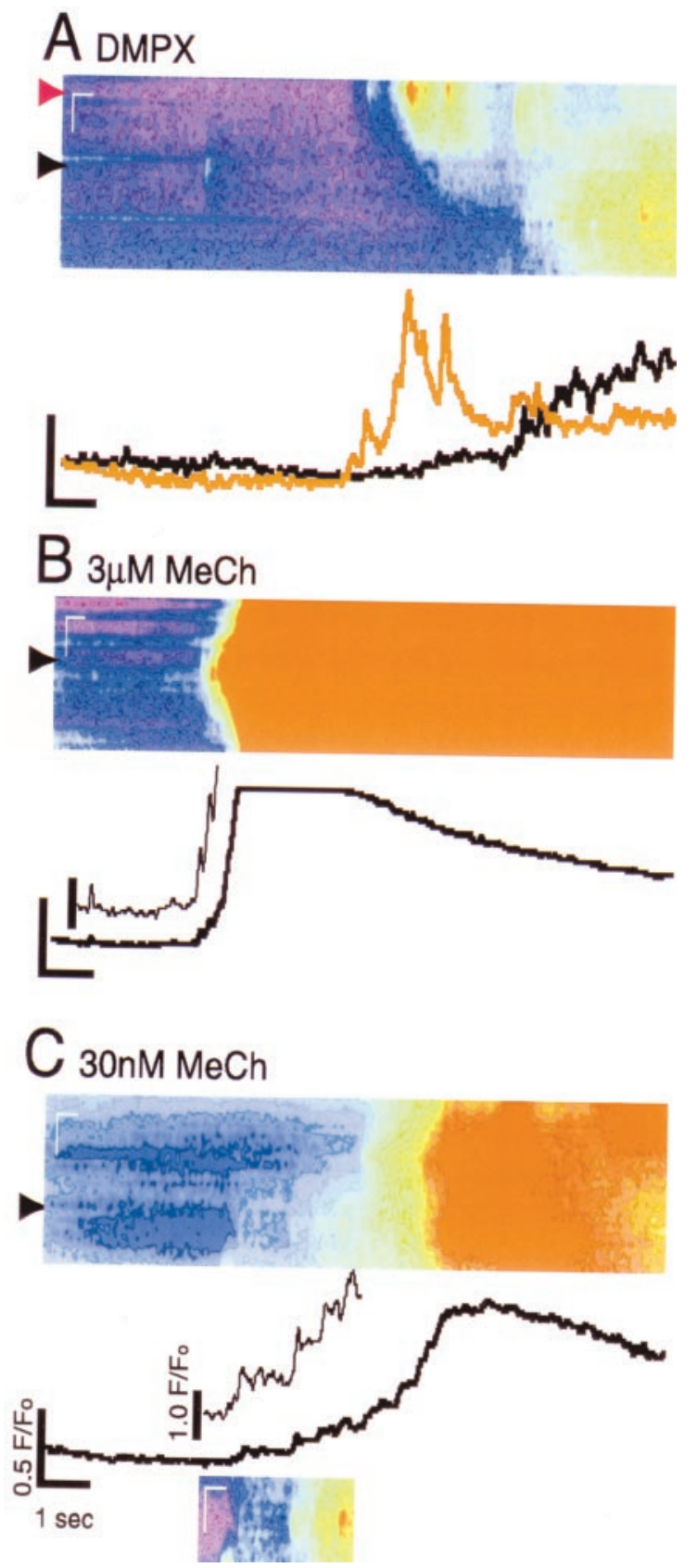

Figure 8. $\quad \mathrm{IP}_{3} \mathrm{Rs}$ and RyRs are differentially linked to wave initiation. Scale for line scans is $400 \mathrm{msec}$ by $8 \mu \mathrm{m}$. Scale for profile plots is $1 \mathrm{sec}$ by $0.5 F / F_{\mathrm{o}} . A$, DMPX evoked sparks of increasing signal mass, frequently atop increasing ambient $\left[\mathrm{Ca}^{2+}\right]_{\mathrm{i}}$. The line scan starts $10 \mathrm{sec}$ after drug application. Local bursts of $\mathrm{Ca}^{2+}$ are evident, but a global wave is not triggered. Profile plots are shown for lines indicated by arrows. B, A $3 \mu \mathrm{M}$ concentration of $\mathrm{MeCh}$ evoked global $\mathrm{Ca}^{2+}$ waves in $>80 \%$ of OPs. Local events appear just before wave onset. In this typical cell, $3 \mu \mathrm{M}$ $\mathrm{MeCh}$ evoked rapidly repeating local events. $\mathrm{A} \mathrm{Ca}^{2+}$ wave initiated at the repeat site. In the profile plot, events appear as small blips on the rising $\mathrm{Ca}^{2+}$ wave. Calibration: $1 \mathrm{sec}, 0.5 F / F_{\mathrm{o}}$. Inset, A section of the profile plot has been enlarged by doubling the $y$-axis $\left(1.0 F / F_{\mathrm{o}}\right)$ to better illustrate the repeating elementary events before the wave. Wave amplitude is $\sim 15$ times larger than elementary event amplitude. $C$, Line scan imaging of OP processes revealed elementary events evoked by $30 \mathrm{~nm} \mathrm{MeCh}$. Events often repeated in the same location and inevitably terminated in a wavelet. Individual repeating events are visible in the profile plot (line indicated by arrow). The line scan inset is shown in stretched pseudocolor scale to illustrate repeating events. The profile inset shows this region with an enlarged $y$ scale $\left(1.0 F / F_{\mathrm{o}}\right)$ illustrating the threefold amplitude difference between elementary events and wavelets. 
cantly slower in cells treated with $30 \mathrm{~nm} \mathrm{MeCh}(3 \mu \mathrm{M}: 120 \pm 3$ $\mu \mathrm{m} / \mathrm{sec}, n=8$; $30 \mathrm{~nm}$ : $23 \pm 0.5 \mu \mathrm{m} / \mathrm{sec}, n=10 ; p=0.0053)$.

The transition from local event to wavelet is best illustrated in Figure $8 C$, which shows $\mathrm{Ca}^{2+}$ release evoked by $30 \mathrm{~nm} \mathrm{MeCh}$. Local events repeated at the same site. As ambient $\left[\mathrm{Ca}^{2+}\right]_{\mathrm{i}}$ increased, so did event size. Neighboring sites were recruited, generating macroevents and then at a critical juncture, a wavelet was triggered. Unlike the global wave shown in Figure $8 B$, the onset and lateral propagation of the wavelet evoked by $30 \mathrm{~nm}$ $\mathrm{MeCh}$ is much slower, and propagation did not proceed $>20 \mu \mathrm{m}$ from the initiation site.

\section{DISCUSSION}

We provide evidence that OPs show spontaneous $\mathrm{Ca}^{2+}$ release events similar to sparks and puffs. The caffeine analog DMPX and the $\mathrm{PLC} / \mathrm{IP}_{3}$-linked agonist $\mathrm{MeCh}$ also evoke spark- and puff-like release events in OPs with distinct spatial and temporal profiles. Interestingly, there appears to be significant cross talk between RyRs and $\mathrm{IP}_{3}$ Rs. Although both DMPX and $\mathrm{MeCh}$ evoke repeating events that show a hierarchy of sizes, only $\mathrm{MeCh}$ events trigger global $\mathrm{Ca}^{2+}$ waves in OPs. We propose that RyRs and $\mathrm{IP}_{3} \mathrm{Rs}$ interact to shape the temporal and spatial characteristics of local and global $\mathrm{Ca}^{2+}$ signals in OPs.

\section{Elementary $\mathbf{C a}^{2+}$ release events}

Since the early 1980 s it has been appreciated that microdomains of very high $\left[\mathrm{Ca}^{2+}\right]_{\mathrm{i}}$ exist in the vicinity of open $\mathrm{Ca}^{2+}$ channels (for review, see Berridge, 1997). $\left[\mathrm{Ca}^{2+}\right]_{i}$ builds up rapidly, stays high as long as the channel is open, then decays exponentially after closure (Naraghi and Neher, 1997). An elementary event may reflect a single channel opening or $\mathrm{Ca}^{2+}$ flux through a small cluster of channels; evidence in favor of the latter is increasing (Thomas et al., 1998; Xun et al., 1998; Gonzalez et al., 2000). With advances in $\mathrm{Ca}^{2+}$ measurement and imaging technology, it is becoming clear that signal selectivity is conferred by spatial restriction and temporal patterning of the $\mathrm{Ca}^{2+}$ signal. For example, in the cerebellum $\mathrm{Ca}^{2+}$ domains in both neurons and glia are thought to determine input specificity for long-term synaptic strength changes (Finch and Augustine, 1998; Grosche et al., 1999). Our data provide evidence that sparks and puffs provide a means for localized signaling in OPs.

The size of a local release event is determined by the number of channels recruited and the $\mathrm{Ca}^{2+}$ flux through individual channels. In OPs, we show that at higher MeCh concentrations, event morphology was significantly different from DMPX-evoked events. Using specific pharmacological tools, we show that RyRand $\mathrm{IP}_{3} \mathrm{R}$-gated channels independently can mediate $\mathrm{Ca}^{2+}$ release from the ER. DMPX is a caffeine analog that acts on the RyR (Bennett et al., 1996), and ryanodine inhibits DMPX-evoked events in OPs. MeCh is known to increase $\mathrm{IP}_{3}$ in OPs (Cohen and Almazan, 1994). Agents that inhibit PLC or the $\mathrm{IP}_{3} \mathrm{R}$, including $\mathrm{XeC}$, also inhibit $\mathrm{MeCh}$-evoked $\mathrm{Ca}^{2+}$ signals, and $\mathrm{MeCh}$ event probability is not affected by ryanodine. That we did not see complete blockade of $\mathrm{MeCh}$ events with $\mathrm{XeC}$ or 2-APB may be attributable to the low concentrations used, slow permeation, or receptor subtype specificity of these antagonists.

De Smet et al. (1999) reported that extended incubation of permeabilized cells with $100 \mu \mathrm{M} \mathrm{XeC}$ depleted stores of $\mathrm{Ca}^{2+}$ by a mechanism involving SERCA pump inhibition. Their conclusion was that $\mathrm{XeC}$ was not a useful tool for investigating the role of $\mathrm{IP}_{3} \mathrm{R}$ in signaling because of its nonspecific actions on membranes. More recently, however, several reports have used much lower concentrations of $\mathrm{XeC}$ to selectively block $\mathrm{IP}_{3} \mathrm{R}$ signaling. For example, $\mathrm{XeC}$ does not induce store-operated channels, which are potentiated by $\mathrm{Ca}^{2+}$ store depletion (Rosado and Sage, 2000; van Rossum et al., 2000). Furthermore, XeC does not affect basal $\mathrm{Ca}^{2+}$ oscillations, but does inhibit $\mathrm{IP}_{3}$-evoked potentiation of oscillations (Miyamoto et al., 2000). In the present report we provide direct measurements of SERCA1 activity in the presence and absence of XeC. SERCA1 exposed to XeC at 50-100 $\mu \mathrm{M}$ for 10-60 min (50-100-fold the concentration needed to fully inhibit $\mathrm{IP}_{3} \mathrm{R}$ ) neither altered thapsigargin-sensitive ATPase activity nor the rates of active $\mathrm{Ca}^{2+}$ accumulation. Similar experiments performed on SERCA2 isolated from rat cardiac muscle also showed insensitivity to $\mathrm{XeC}$ (data not shown). Taken together, these results demonstrate that $\mathrm{XeC}$ lacks direct inhibitory activity toward SERCA pumps and can be used successfully to probe the role of $\mathrm{IP}_{3} \mathrm{R}$ in signaling.

OPs express specific $\mathrm{Ca}^{2+}$ release channel subtypes: RyR3 and $\mathrm{IP}_{3} \mathrm{R} 2$. These receptors are expressed in patches along OP processes, similar to $\mathrm{Ca}^{2+}$ wave propagation sites in other glial cells (Simpson et al., 1997; Laskey et al., 1998). RyRs are coexpressed with $\mathrm{IP}_{3} \mathrm{Rs}$ in some patches, but $\mathrm{IP}_{3} \mathrm{Rs}$ are also found alone. This differential distribution pattern may underlie the differences in local and global $\mathrm{Ca}^{2+}$ signals mediated by these two receptors. Dual regulation of $\mathrm{Ca}^{2+}$ release from the ER has been shown in other CNS cells. In neurons and PC12 cells, $\mathrm{IP}_{3} \mathrm{Rs}$ and RyRs appear to cluster together and mediate localized $\mathrm{Ca}^{2+}$ signaling (Koizumi et al., 1999). Thus, it is possible that instead of different subtypes of $\mathrm{IP}_{3} \mathrm{Rs}$ combining to regulate $\mathrm{Ca}^{2+}$ release (Miyakawa et al., 1999), in OPs RyR3 and $\mathrm{IP}_{3} \mathrm{R} 2$ interact to adapt $\mathrm{Ca}^{2+}$ signals to specific physiological functions.

\section{Wave initiation is mediated by $I P_{3} R s$}

In OPs, $\mathrm{Ca}^{2+}$ wave initiation seems to be dependent on activation of $\mathrm{IP}_{3}$ Rs. Wave onset slope and propagation speed were proportional to $\mathrm{MeCh}$ concentration. Wave speed was similar to that reported in other glial cells (Dani et al., 1992; Yagodin et al., 1994). It appeared that local release events raised the ambient $\left[\mathrm{Ca}^{2+}\right]_{\mathrm{i}}$ until at some threshold, a wave was triggered. At lower $\mathrm{MeCh}$ concentrations, more discrete events preceded wave initiation, and global waves were reduced to wavelets with a spatial spread that did not exceed our field of view $(<40 \mu \mathrm{m})$. At higher concentrations of $\mathrm{MeCh}$, this initiation process took less time, so that events repeated with shorter time intervals and were buried in the wave onset.

The $\mathrm{IP}_{3} \mathrm{R}$-gated ion channel is under dual-ligand control, requiring both $\mathrm{Ca}^{2+}$ and $\mathrm{IP}_{3}$ (Moraru et al., 1999). Graded $\mathrm{Ca}^{2+}$ signals are composed of autonomous elementary events. Increasing signal strength activates more receptors until signal strength reaches a threshold level when events become coordinated to produce a global signal (Lechleiter and Clapham, 1992; Marchant et al., 1999). We show that wave initiation in OPs fits this paradigm: local events coordinate to produce a global signal; the efficiency of coordination is dependent on both $\mathrm{IP}_{3}$ and $\left[\mathrm{Ca}^{2+}\right]_{\mathrm{i}}$. Such a mechanism of wave propagation has been proposed in a number of model systems (Bezprozvanny, 1994; Roth et al., 1995; Tang et al., 1996; Dawson et al., 2000).

Interestingly, we found that OPs express only $\mathrm{IP}_{3} \mathrm{R} 2 \mathrm{~s}$. In singlechannel studies, Ramos-Franco et al. (1998) found the $\mathrm{IP}_{3} \mathrm{R} 2$ isoform showed striking sensitivity to $\mathrm{IP}_{3}$ and $\left[\mathrm{Ca}^{2+}\right]_{\mathrm{i}}$, resulting in $\mathrm{Ca}^{2+}$ mobilization substantially greater than on activation of $\mathrm{IP}_{3} \mathrm{R} 1$. In addition, they found that high $\left[\mathrm{Ca}^{2+}\right]_{\mathrm{i}}$ did not inhibit $\mathrm{IP}_{3} \mathrm{R} 2 \mathrm{~s}$ as it does $\mathrm{IP}_{3} \mathrm{R} 1 \mathrm{~s}$. With this kinetic profile, the $\mathrm{IP}_{3} \mathrm{R} 2$ 
seems well suited for triggering $\mathrm{Ca}^{2+}$ waves. Indeed, the IP3R2 is necessary for the expression of long-lasting $\mathrm{Ca}^{2+}$ oscillations in B-cells (Miyakawa et al., 1999).

Although $\mathrm{IP}_{3} \mathrm{Rs}$ trigger global $\mathrm{Ca}^{2+}$ waves in OPs, RyR-gated $\mathrm{Ca}^{2+}$ release seems to act on a more restricted spatial scale. DMPX never elicited waves in OPs. Instead, it appeared that RyRs are activated at low $\left[\mathrm{Ca}^{2+}\right]_{\mathrm{i}}$, and as levels increase, event size increased but did not trigger a propagating $\mathrm{Ca}^{2+}$ wave. We show that OPs express RyR3. Studies in RyR null-mutant mice indicate that RyR3 activation generates sparks but does not support excitation-contraction coupling (Conklin et al., 1999, 2000). Single-channel studies have shown that RyR3 is caffeineand ryanodine-sensitive, that $\mathrm{Ca}^{2+}$ alone can activate $\mathrm{RyR} 3$, and that the channel shows a bell-shaped activation by $\mathrm{Ca}^{2+}$ (Chen et al., 1997). Activation of the RyR3 in OPs appears to evoke highly localized $\mathrm{Ca}^{2+}$ signals. Certainly, local $\mathrm{Ca}^{2+}$ release from intracellular stores is critically important for cell guidance and migration during brain development (Simpson and Armstrong, 1999; Zheng, 2000).

\section{Cross talk between RyR and IP $P_{3} R$}

In addition to their separate roles, in OPs $\mathrm{IP}_{3} \mathrm{Rs}$ and RyRs appear to modulate each other. Ryanodine, which inhibited DMPX events, caused MeCh-evoked events to become wider and taller. RyRs may be exerting an inhibitory influence on neighboring $\mathrm{IP}_{3} \mathrm{Rs}$, perhaps by preferentially binding $\mathrm{Ca}^{2+}$. On the other hand, ryanodine blockade of the RyR may prevent a $\mathrm{Ca}^{2+}$ leak from the ER and thereby enhance responsiveness of $\mathrm{IP}_{3} \mathrm{Rs}$ located on the same stores.

Potentiation of DMPX-evoked events by MeCh took several minutes to develop. This can be explained in at least two ways: (1) activation of $\mathrm{Ca}^{2+}$ release channels promotes clustering of $\mathrm{IP}_{3} \mathrm{Rs}$ and/or RyRs into homoreceptor or heteroreceptor patches. When receptors are in closer proximity, the same size signal will activate more receptors through $\mathrm{Ca}^{2+}$-induced $\mathrm{Ca}^{2+}$ release. In some systems, neurotransmitters can promote receptor aggregation and even heterodimerization (Sabatini et al., 1999; Rocheville et al., 2000). $\mathrm{IP}_{3} \mathrm{R} 2$ clustering is induced by stimulation of muscarinic receptors in hamster lung fibroblast cells (Wilson et al., 1998). Clustering occurred within 5-10 min of stimulus, about the same time frame seen in OPs for DMPX event potentiation by pretreatment with $\mathrm{MeCh}$. In muscle cells, allosteric interactions have been shown to be important for RyR activity (Stern et al., 1999). (2) Activity of either receptor may be altered by post-translational modification. In addition to movement within the ER membrane, $\mathrm{IP}_{3} \mathrm{Rs}$ and RyRs are potentiated by association with accessory proteins such as calmodulin (for review, see Makrill, 1999) or by phosphorylation (Bird et al., 1993; Nakade et al., 1994). In OPs, MeCh acts through a $\mathrm{G}_{\mathrm{q}}$-coupled cell surface receptor linked to MAP kinase and cAMP kinase activity (Pende et al., 1997). In other cells, activation of $\mathrm{G}_{\mathrm{q}}$-coupled plasma membrane receptors is sufficient to cause phosphorylation of the cAMP-dependent protein kinase A (Wojcikiewicz and Luo, 1998), which can potentiate the $I_{3} R$ and RyR by phosphorylating FKBP (Cameron et al., 1997; Marx et al., 2000).

\section{Functional implications}

Unlike sparks and puffs in other cell types, local events in OPs rarely arise spontaneously, suggesting that $\mathrm{Ca}^{2+}$ release from the $\mathrm{ER}$ is tightly regulated. Indeed, $\mathrm{Ca}^{2+}$ release from intracellular stores in OPs is critical for transduction of signals that promote proliferation and differentiation into myelin-producing cells (Co- hen et al., 1996). Many plasma membrane receptors are downregulated after OP differentiation (Kastritis and McCarthy, 1993; He and McCarthy, 1994), a process that seems to be dependent on neuronal activity (He et al., 1996). As in neurons, $\mathrm{Ca}^{2+}$ microdomains evoked by transmitter or growth factor release from neighboring cells may mediate process extension and pathfinding in OPs. Once OPs find a neuron to myelinate, global $\mathrm{Ca}^{2+}$ signals in response to neuronal activity may activate gene transcription and ultimately cell differentiation (Barres and Raff, 1993; Stevens and Fields, 2000).

\section{REFERENCES}

Barres BA, Raff MC (1993) Proliferation of oligodendrocyte precursor cells depends on electrical activity in axons. Nature 361:258-260.

Barres BA, Schmid R, Sendtner M, Raff MC (1993) Multiple extracellular signals are required for long-term oligodendrocyte survival. Development 118:283-295.

Bennett D, Cheek T, Berridge M, DeSmedt H, Parys J, Missiaen L, Bootman M (1996) Expression and function of ryanodine receptors in nonexcitable cells. J Biol Chem 271:6356-6362.

Berridge MJ (1997) Elementary and global aspects of calcium signalling. J Physiol (Lond) 499:291-306.

Bezprozvanny I (1994) Theoretical analysis of calcium wave propagation based on inositol(1,4,5)-trisphosphate (InsP3) receptor functional properties. Cell Calcium 16:151-166.

Bird GS, Burgess GM, Putney JW (1993) Sulfhydryl reagents and cAMP-dependent kinase increase the sensitivity of the inositol 1,4,5trisphosphate receptors. J Biol Chem 268:17917-17923.

Callamaras N, Parker I (1999) Radial localization of inositol 1,4,5trisphosphate-sensitive $\mathrm{Ca}^{2+}$ release sites in Xenopus oocytes resolved by axial confocal line scan imaging. J Gen Physiol 113:199-213.

Calver AR, Hall AC, Yu WP, Walsh FS, Heath JK, Betsholtz C, Richardson WD (1998) Oligodendrocyte population dynamics and the role of PDGF in vivo. Neuron 20:869-882.

Cameron AM, Nucifora FC, Fung ET, Livingston DJ, Aldape RA, Ross CA, Snyder SH (1997) FKBP12 binds the inositol 1,4,5-trisphosphate receptor at leucine-proline (1400-1401) and anchors calcineurin to this FK506-like domain. J Biol Chem 272:27582-27588.

Chen SRW, Li XL, Ebisawa K, Zhang L (1997) Functional characterization of the recombinant type $3 \mathrm{Ca}^{2+}$ release channel (ryanodine receptor) expressed in HEK293 cells. J Biol Chem 272:24234-24246.

Cheng H, Lederer WJ, Cannell MB (1993) Calcium sparks: Elementary events underlying excitation-contraction coupling in heart muscle. Science 262:740-744.

Cheng H, Lederer M, Xiao R, Gomez A, Zhou Y, Ziman B, Spurgeon H, Lakatta E, Lederer W (1996) Excitation-contraction coupling in heart: new insights from $\mathrm{Ca}^{2+}$ sparks. Cell Calcium 20:129-140.

Cheng H, Song LS, Shirokova N, Gonzalez A, Lakatta EG, Rios E, Stern MD (1999) Amplitude distribution of calcium sparks in confocal images: Theory and studies with an automatic detection method. Biophys J 76:606-617.

Cohen RI, Almazan GS (1994) Rat oligodendrocytes express muscarinic receptors coupled to phosphoinositide hydrolysis and adenylyl cyclase. Eur J Neurosci 6:1213-1224.

Cohen R, Molina-Holgado E, Almazan G (1996) Carbachol stimulates c-fos expression and proliferation in oligodendrocyte progenitors. Mol Brain Res 43:193-201.

Conklin M, Barone V, Sorrentino V, Coronado R (1999) Contribution of ryanodine receptor type 3 to $\mathrm{Ca}^{2+}$ sparks in embryonic mouse skeletal muscle. Biophys J 77:1394-1403.

Conklin MW, Ahern CA, Vallejo P, Sorrentino V, Takeshima H, Coronado $\mathrm{R}$ (2000) Comparison of $\mathrm{Ca}^{2+}$ sparks produced independently by two ryanodine receptor isoforms (type 1 or type 3 ). Biophys J 78:1777-1785.

Dani JW, Chernjavsky A, Smith SJ (1992) Neuronal activity triggers calcium waves in hippocampal astrocyte networks. Neuron 8:429-440.

Dawson SP, Keizer J, Pearson JE (2000) Fire-diffuse-fire model of dynamics of intracellular calcium waves. Proc Natl Acad Sci USA 96:6060-6063.

De Smet P, Parys JB, Callewaert G, Weidema AF, Hill E, De Smedt H, Erneux C, Sorrentino V, Missiaen L (1999) Xestospongin C is an equally potent inhibitor of the inositol 1,4,5-trisphosphate receptor and the endoplasmic-reticulum $\mathrm{Ca}^{2+}$ pumps. Cell Calcium 26:9-13.

Fatatis A, Miller RJ (1997) Platelet-derived growth factor (PDGF)induced $\mathrm{Ca}^{2+}$ signaling in the CG4 oligodendroglial cell line and in transformed oligodendrocytes expressing the $\beta$-PDGF receptor. J Biol Chem 272:4351-4358.

Feng W, Liu G, Xia R, Abramson JJ, Pessah IN (1999) Site-selective modification of hyperreactive cysteines of ryanodine receptor complex by quinones. Mol Pharmacol 55:821-831. 
Finch EA, Augustine GJ (1998) Local calcium signalling by inositol1,4,5-trisphosphate in Purkinje cell dendrites. Nature 396:753-756.

Gafni J, Munsch JA, Lam TH, Catlin MC, Costa LG, Molinski TF, Pessah IN (1997) Xestospongins: potent membrane permeable blockers of the inositol 1,4,5-trisphosphate receptor. Neuron 19:723-733.

Gonzalez A, Kirsch WG, Shirokova N, Pizarro G, Brum G, Pessah IN, Stern MD, Cheng H, Rios E (2000) Involvement of multiple intracellular release channels in calcium sparks of skeletal muscle. Proc Natl Acad Sci USA 97:4380-4385.

Grosche J, Matyash V, Moller T, Verkhratsky A, Reichenbach A, Kettenmann H (1999) Microdomains for neuron-glia interaction: parallel fiber signaling to Bergmann glial cells. Nat Neurosci 2:139-143.

Hagar RE, Burgstahler AD, Nathanson MH, Ehrlich BE (1998) Type III InsP $_{3}$ receptor channel stays open in the presence of increased calcium. Nature 396:81-84.

He M, McCarthy KD (1994) Oligodendroglial signal transduction systems are developmentally regulated. J Neurochem 63:501-508.

He M, Howe DG, McCarthy KD (1996) Oligodendroglial signal transduction systems are regulated by neuronal contact. J Neurochem 67:1491-1499.

Kastritis CH, McCarthy KD (1993) Oligodendroglial lineage cells express neuroligand receptors. Glia 8:106-113.

Kirischuk S, Sherer T, Möller T, Verkhratsky A, Kettenman H (1995) Subcellular heterogeneity of voltage-gated $\mathrm{Ca}^{2+}$ channels in cells of the oligodendrocyte lineage. Glia 13:1-2.

Koizumi S, Bootman MD, Bobanovic LK, Schell MJ, Berridge MJ, Lipp $P$ (1999) Characterization of elementary $\mathrm{Ca}^{2+}$ release signals in NGF-differentiated PC12 cells and hippocampal neurons. Neuron 22:125-137.

Krämer E-M, Klein C, Koch T, Boytinck M, Trotter J (1999) Compartmentation of Fyn kinase with glycosylphosphatidylinositol-anchored molecules in oligodendrocytes facilitates kinase activation during myelination. J Biol Chem 274:29042-29049.

Laskey AD, Roth BJ, Simpson PB, Russell JT (1998) Images of $\mathrm{Ca}^{2+}$ flux in astrocytes: evidence for spatially distinct sites of $\mathrm{Ca}^{2+}$ release and uptake. Cell Calcium 23:423-432.

Lechleiter JD, Clapham DE (1992) Molecular mechanisms of intracellular calcium excitability in X. laevis oocytes. Cell 69:283-294.

Makrill JJ (1999) Protein-protein interactions in intracellular $\mathrm{Ca}^{2+}$. release channel function. Biochem J 337:345-361.

Marchant JS, Parker I (1998) Kinetics of elementary $\mathrm{Ca}^{2+}$ puffs evoked in Xenopus oocytes by different Ins $(1,4,5) \mathrm{P}_{3}$ receptor agonists. Biochem J 334:505-509.

Marchant J, Callamaras N, Parker I (1999) Initiation of IP $_{3}$-mediated $\mathrm{Ca}^{2+}$ waves in Xenopus oocytes. EMBO J 18:5285-5299.

Maruyama T, Kanaji T, Nakade S, Kanno T, Mikoshiba K (1997) 2-APB, 2-aminoethoxydiphenyl borate, a membrane-penetrable modulator of Ins $(1,4,5) \mathrm{P}_{3}$-induced $\mathrm{Ca}^{2+}$ release. J Biochem 122:498-505.

Marx SO, Reiken S, Hisamatsu Y, Jaymaran T, Burkoff D, Rosemblit N, Marks AR (2000) PKA phosphorylation dissociates FKBP12.6 from the calcium release channel (Ryanodine receptor): defective regulation in failing hearts. Cell 101:365-376.

Miyakawa T, Maeda A, Yamazawa T, Hirose K, Kurosaki T, Iino M (1999) Encoding of $\mathrm{Ca}^{2+}$ signals by differential expression of $\mathrm{IP}_{3}$ receptor subtypes. EMBO J 18:1303-1308.

Miyamoto S, Izumi M, Hori M, Kobayashi M, Ozaki H, Karaki H (2000) Xestospongin $\mathrm{C}$, a selective and membrane-permeable inhibitor of $\mathrm{IP}_{3}$ receptor, attenuates the positive inotropic effect of alpha-adrenergic stimulation in guinea-pig papillary muscle. Br J Pharmacol:650-654.

Moraru II, Kaftan EJ, Ehrlich BE, Watras J (1999) Regulation of type 1 inositol 1,4,5-trisphosphate-gated calcium channels by $\mathrm{InsP}_{3}$ and calcium: simulation of single channel kinetics based on ligand binding and electrophysiological analysis. J Gen Physiol 113:837-849.

Murayama T, Ogawa Y (1996) Properties of RyR3 ryanodine receptor isoform in mammalian brain. J Biol Chem 271:5079-5084.

Nakade S, Rhee SK, Hamanaka H, Mikoshiba K (1994) Cyclic-AMPdependent phosphorylation of an immunoaffinity-purified homotetrameric inositol 1,4,5-trisphosphate receptor (type-1) increases $\mathrm{Ca}^{2+}$ flux in reconstituted lipid vesicles. J Biol Chem 269:6735-6742.

Naraghi M, Neher E (1997) Linearized buffered $\mathrm{Ca}^{2+}$ diffusion in microdomains and its implications for calculation of $\left[\mathrm{Ca}^{2+}\right]$ at the mouth of a calcium channel. J Neurosci 17:6961-6973.

Noble M, Murray K, Stroobant P, Waterfield MD, Riddle P (1988) Platelet-derived growth factor promotes division and motility and inhibits premature differentiation of the oligodendrocyte/type- 2 astrocyte progenitor cell. Nature 333:560-562.

Palade P (1987) Drug-induced $\mathrm{Ca}^{2+}$ release from isolated sarcoplasic reticulum. I. Use of pyrophosphate to study caffeine induced $\mathrm{Ca}^{2+}$ release. J Biol Chem 262:6135-6141.

Parker I, Choi J, Yao Y (1996) Elementary events of InsP3-induced $\mathrm{Ca}^{2+}$ liberation in Xenopus oocytes: hot spots, puffs and blips. Cell Calcium 20:105-121.

Pende M, Fischer TL, Simpson PB, Russell JT, Blenis J, Gallo V (1997) Neurotransmitter- and growth factor-induced cAMP response element binding protein phosphorylation in glial cell progenitors: role of cal- cium ions, protein kinase $\mathrm{C}$, and mitogen activated protein kinase/ ribosomal S6 pathway. J Neurosci 17:1291-1301.

Ramos-Franco J, Fill M, Mignery GA (1998) Isoform-specific function of single inositol 1,4,5-trisphosphate receptor channels. Biophys J 75:834-839.

Redwine JM, Armstrong RC (1998) In vivo proliferation of oligodendrocyte progenitors expressing PDGF $\alpha \mathrm{R}$ during early remyelination. J Neurobiol 37:413-428.

Rocheville M, Lange DC, Kumar U, Patel SC, Patel RC, Patel YC (2000) Receptors for dopamine and somatostatin: formation of heterooligomers with enhanced functional activity. Science 288:154-157.

Rosado JA, Sage SO (2000) Coupling between inositol 1,4,5trisphosphate receptors and human transient receptor potential channel 1 when intracellular $\mathrm{Ca}^{2+}$ stores are depleted. Biochem J 350:631-635.

Roth BJ, Yagodin SV, Holtzclaw L, Russell JT (1995) A mathematical model of agonist-induced propagation of calcium waves in astrocytes. Cell Calcium 17:53-64.

Sabatini DM, Barrow RK, Blackshaw S, Burnett PE, Lai MM, Field ME, Bahr BA, Kirsch J, Betz H, Snyder SH (1999) Interaction of RAFT1 with gephyrin required for rapamycin-sensitive signaling. Science 284:1161-1164

Saito A, Seiler S, Chu A, Fleischer S (1984) Preparation and morphology of sarcoplasmic reticulum terminal cisternae from rabbit skeletal muscle. J Cell Biol 99:875-885.

Sato-Bigbee C, Pal S, Chu AK (1999) Different neuroligands and signal transduction pathways stimulate CREB phosphorylation at specific developmental stages along oligodendrocyte differentiation. J Neurochem 72:139-147.

Schwartz A, Allen JC, Harigaya S (1969) Possible involvement of cardiac $\mathrm{Na}^{+}, \mathrm{K}^{+}$-adenosine triphosphatase in the mechanism of action of cardiac glycosides. J Pharmacol Exp Ther 168:31-41.

Sharp AH, Nucifora FC, Blondel O, Sheppard CA, Zhang CY, Snyder SH, Russell JT, Ryugo DK, Ross CA (1999) Differential cellular expression of isoforms of inositol 1,4,5-triphosphate receptors in neurons and glia in brain. J Comp Neurol 406:207-220.

Simpson PB, Armstrong RA (1999) Intracellular signals and cytoskeletal elements involved in oligodendrocyte progenitor migration. Glia 26:22-35.

Simpson PB, Russell JT (1996) Mitochondria support inositol 1,4,5trisphosphate-mediated $\mathrm{Ca}^{2+}$ waves in cultured oligodendrocytes. J Biol Chem 271:33493-33501.

Simpson PB, Mehotra S, Lange GD, Russell JT (1997) High density distribution of endoplasmic reticulum proteins and mitochondria at specialized $\mathrm{Ca}^{2+}$ release sites in oligodendrocyte processes. J Biol Chem 272:22654-22661.

Song L-S, Stern MD, Lakatta EG, Cheng HP (1997) Partial depletion of sarcoplasmic reticulum calcium does not prevent calcium sparks in rat ventricular myocytes. J Physiol (Lond) 505:665-675.

Stern M, Song L, Cheng H, Sham J, Yang H, Boheler K, Rios E (1999) Local control models of cardiac excitation-contraction coupling: a possible role for allosteric interactions between ryanodine receptors. J Gen Physiol 113:469-489.

Stevens B, Fields RD (2000) Response of Schwann cells to action potentials in development. Science 287:2267-2271.

Sun H-Q, Lin H-M, Yin HL (1997) Gelsolin modulates phopholipase C activity in vivo through phospholipid binding. J Cell Biol 138:811-820.

Tang YH, Stephenson JL, Othmer HG (1996) Simplification and analysis of models of calcium dynamics based on $\mathrm{IP}_{3}$-sensitive calcium channel kinetics. Biophys J 70:246-263.

Thomas D, Lipp P, Berridge MJ, Bootman MD (1998) Hormone-evoked elementary $\mathrm{Ca}^{2+}$ signals are not stereotypic, but reflect activation of different size channel clusters and variable recruitment of channels within a cluster. J Biol Chem 273:27130-27136.

van Rossum DB, Patterson RL, Ma HT, Gill DL (2000) $\mathrm{Ca}^{2+}$ entry mediated by store depletion, S-nitrosylation and TRP3 channels: comparison of coupling and function. J Biol Chem 275:28562-28568.

Walton PD, Airey JA, Sutko JL, Beck CF, Mignery GA, Sudhof GA, Deerinck TJ, Ellisman MH (1991) Ryanodine and inositol trisphosphate receptors coexist in avian cerebellar Purkinje neurons. J Cell Biol 113:1145-1157.

Wilson BS, Pfeiffer JR, Smith AJ, Oliver JM, Oberdorf JA, Wojcikiewicz RJH (1998) Calcium-dependent clustering of inositol 1,4,5trisphosphate receptors. Mol Biol Cell 9:1465-1478.

Wojcikiewicz R, Luo S (1998) Phosphorylation of inositol 1,4,5trisphosphate receptors by cAMP-dependent protein kinase: type I, II and III receptors are differentially susceptible to phosphorylation and are phosphorylated in intact cells. J Biol Chem 273:5670-5677.

Xun XP, Callamaras N, Marchant JS, Parker I (1998) A continuum of $\mathrm{InsP}_{3}$-mediated elementary $\mathrm{Ca}^{2+}$ signalling events in Xenopus oocytes. J Physiol (Lond) 509:67-80.

Yagodin S, Holtzclaw L, Sheppard C, Russell J (1994) Nonlinear propagation of agonist-induced cytoplasmic calcium waves in single astrocytes. J Neurobiol 25:265-280.

Zheng JQ (2000) Turning of nerve growth cones induced by localized increases in intracellular calcium ions. Nature 403:89-93. 